\section{THE DECADE OF VILOENT \\ DESTABILIZATION IN NEPAL: AN ANALYSIS OF ITS HISTORICAL BACKGROUND AND TRAJECTORY}

\section{Tone Bleie}

This article' will discuss how the negotiations over the defining attributes of state authority and of state-society relations at important conjunctures in Nepal's recent political history are related to political and economic conditions with national, regional and global outreach. The unravelling of the intricate interplay between internal and external structural conditions and major national political events over nearly five decades $(1950-1996)$ questions any facile characterisation of the Maoist rebellion (which started in 1996) as an internal conflict only. The exposition moreover questions any characterisation of the Nepalese state as increasingly "developmentalist" and hence accountable from a rightsbased perspective (see Bleie et. al, 2000).

The main analytical focus of this article is on the structural conditions and agency actions that resulted in 1996 in a Maoist-led rebellion in this richly endowed Himalayan kingdom. ${ }^{2}$ This focus inevitably raises the need for an analytical framework to explain the causes of the inception of the Maoist uprising in Nepal. To outline the whole network of interacting ultimate and proximate causes and effects is exceedingly demanding, analytically speaking, as well as space consuming, and thus too tall an order for an article. Instead, this article seeks to establish a more tentative explanatory framework of the dialectic between structural conditions and agency actions, which to some degree explains both some enduring features of the autocratic state and its ability to adapt - at least for an intermediate period over the last 50 years under dramatically changing circumstances. Well-known historical events, including the palace revolt in 1951, the democratic reforms of 1959 , the 1980 referendun, the People's Movement in 1990, the declaration of People's War in 1996 and the April Movement in 2006, are analysed by combining insights from political science, public administration and anthropology. A straightforward instrumentalist view of government that conceptualises policy as technical, rational, actionoriented instruments for effecting change is supplemented by an anthropological view of govemance (see Shore and Wright, 2001). This view conceptualises governance as governed by more complex and diffuse symbolic processes which establish indigenous institutional rules and codes of conduct that are internalised. Through these processes, certain fundamental tenets of the prevailing order of governance are naturalised and therefore scarcely subjected to reflection. Such a perspective is applied in order to explain the strikingly widespread and deeply-felt belief in the sacrosanct Hindu monarchy among supporters both of the autocratic regime and of liberal democracy.

This view of governance, derived from political anthropology, also gains analytical strength from drawing on a more comprehensive theory of the nature of this Hindu state and its underlining cultural models of divine kingship, sovereignty, body politic and the nature of cultural diversity. ${ }^{3}$ This analytical approach to governance is found to be useful in explaining how and why the monarch has been unaccountable until the historical decision in 2006 of the reinstated House of Representatives, and how the bureaucracy in Nepal has been imbued with an institutional logic based on patronage and loyalty, a logic unlike the Western notion of accountability as answerability to human rights concerns. ${ }^{4}$ While Nepal's rulers, for purely pragmatic reasons, in the period between 1950 and 1990 tapped legitimacy through a development discourse, the internal workings of the government, bureaucracy and public domain created few incentives for establishing basic accountability mechanisms. ${ }^{5}$

In 1990, the People's Movement (Jana Andolan) fought through a new democratic constitution. This led to the creation of a democratically elected government, which subsequently ratified a number of human rights conventions. These unprecedented events promised a new era of intensified efforts to institutionalise basic accountability mechanisms. The reasons why such high expectations were dashed will be explored. 
The discussions in this article are confined to analysing most, if not all, the structural conditions for the violent conflict between the state and the military and political movement led by the Communist Party of Nepal (Maoist). Thus, the exposition is not meant to cover all the necessary and sufficient causes for the rapid escalation of the conflict which has over the last decade engulfed large parts of the country in civil war and led to a reduced presence (and in certain areas full withdrawal) of the "old state's" functions. This does not detract from the fact that a number of the structural causes outlined here are of considerable relevance in understanding the escalation of the conflict, including the otherwise inexplicable positions of the main stakeholders (the ruling monarch, the Royal Nepalese Army, the mainstream political parties and the Communist Party of Nepal (Maoist) in a situation that seem nearly unsolvable, but eventually ended in a Comprehensive Peace Accord in late 2006

In order to be able to cast some light on the degree of continuity and change in the Hindu state, the article starts out with a brief analysis of the state since the unification of Nepal in the late eighteenth century. This is intended to clarify and explicate the salient structural features of the state in 1951, including its underpinning cultural models, when strictly autocratic rule ended and a period of early contestation of the Hindu state began. The article argues for caution against sweeping assertions about the political history of the last half century as a period of shifts between autocratic and democratic government. It argues instead that the old political regime underwent certain restructurings as it reasserted its political dominance through a dramatic expansion of a bureaucracy with a modem appearance, but govemed by institutional rules and practices grounded in an upper-caste, patronage-oriented court culture. This massive expansion of the state apparatus only created the appearance of a progressive Nepalese accommodation to international norms of democracy and a redistributive and accountable state ensuring human rights. In real terms, the expansion led to a certain upward mobility predominantly of men from the higher castes, whose co-option into the state apparatus allowed a revitalisation of the old regime. This restructured and consolidated regime could now, though bureaucratic expansion and legitimate development rhetoric, directly penetrate rural society and pursue a policy of centralisation in spite of its rhetoric to the contrary.
Thus, it is only apparently a paradox that the integration of the mountain kingdom into the world community (accompanied by a large influx of development assistance) enabled the regime to tap both Westem and indigenous sources of legitimacy. Donor assistance was used by the regime to expand a bureaucracy that emulated the old patronage culture, now flourishing on generous monetary and technical assistance. While helping to ensure the hegemonic grip of the old autocratic regime in the shorter run, the development assistance also had other contradictory effects, reinforcing economic differentiation, restructuring social disparities and transforming political consciousness of ethnic, caste and gender-based injustices at both collective and individual levels

While both international political developments and development assistance in the four principal development decades (1960s to 1990s) engendered first the seeds and later the ferment of political dissent centred on a Westem liberal discourse on the nature of the state and state-society relations - there was another set of national actors who represented an altemative chorus of dissenting voices, based on MarxistLeninist and Maoist political ideology. This stream of political thought, which claimed to be scientific and of universal applicability, contained a comprehensive set of propositions about the nature of world history, of global/regional and national interdependencies, and thus also of Nepal's history. Based on this political ideology, the communists had, from their establishment of the first communist party, challenged the autocratic monarchy and called for a constituent assembly in order to create what they coin "the objective conditions" for a radical rupture in the old political order and the genesis of "a new state".

This state would effectively combat gender, caste, ethnic and regional oppression. In recognition of the importance of this growing political movement and its regional basis, the article briefly describes the major shifts in the institutionalisation of communism in Nepal, through bewilderingly numerous fissions and fusions. These were at times the results of personality-based politics and other more pragmatic postures. But the fissions and fusions were at times the results of deep ideological dissent, resulting in the purging of minority views.

The article eventually focuses on the sudden rise in 1990 of a popular movement, which led to a new constitution that enshrined 
constitutional monarchy and multi-party democracy. Three main lines of argument are developed about the 1990/91 events and the following period up to the proclamation of the insurgency. Firstly, the article pinpoints that the cultural hegemony of the notion of Hindu monarchy and certain intemational and national political constellations resulted in a quelled mass movement and an incongruous constitution. Secondly, the article stresses the importance of 1990/91 and the following years as a radical juncture for the communist movement in Nepal. Some of these leftist parties became parliamentary actors. One newly merged communist party (Communist Party of Nepal Unified Marxist-Leninist) turned to social democratic ideology and went into government. Three other Maoist and outrightly republican parties, though opposed to the constitution and the multiparty system, created first a political front (the Unity Centre) so as to expose tactically the inadequacies of the parliamentary system, then later withdrew from parliamentary politics, while utilising the expanded liberties of civil society to make an unprecedented comeback. Thirdly, the reasons for the failure of both leftist and rightist democratic parties to build effective coalitions around national interests and to start institutionalising a democratic transition are outlined. This blatant failure to embark on a road of democratisation may be understood as much as an effect of the old regime's political and mental grip over policy making and administration.

But, this effect led, in turn, to an intolerable disjuncture between on the one hand a fermenting and spreading consciousness of political grievances (in a civil society invariably moulded by foreign development aid and the communist movement) and on the other, the state's failure to start responding to basic democratic demands, through the establishment of accountability mechanisms. In fact, the state instead took on a conflict-inducing and escalating role, resorting to repressive means through the intact, authoritarian state apparatus. The constellation of these internal conditions and in addition the ideological victory (within the Unity Centre) of the hardliners in favour of armed struggle left the ground fertile for the declaration in February 1996 by the Communist Party of Nepal (Maoist) of the political and military programme of a socalled "People's War". This programme aimed at creating a mass-based movement through first establishing so-called 'base areas' in the remote rural areas, and then later surrounding urban areas and seizing state power. The Comprehensive Peace Accord of November 2006 can be characterised as a victory for the Communist Party of Nepal (Maoist), though they have for pragmatic reasons conceded to a deal that is based on liberal democratic values.

\section{THE RISE OF THE HINDU STATE IN NEPAL}

\section{Unification and Early Consolidation during the Shahs (1768-1846)}

Both in the South-Indian region and Indo-Gangetic region, a number of expansionist kingdoms rose during the medieval period. They were organised on religions based on sophisticated textual sources, on the culture of caste and Hinduism, and on sacred kings considered gods and great conquerors (Inden, 1990). The rise of Hindu kingdoms in the foot and mid-hill Himalayan region should be seen as part of these regionwide trends in state-formation. The unification of Nepal in the middle and late eighteenth century by Prithivi Narayan Shah was based on a combination of military force, marriage alliances between immigrants and ethnic elites, state patronage of earlier local or regional deities, exterminating some contending chiefly lines while offering others highranking of fice, and promoting the migration of Hindus to tribal domains. ${ }^{6}$ As a result of the alliance between Hindu settlers and central elites, tribal lands were turned into state lands or cleared for cultivation. This resulted in increased taxation which accrued to the state treasury.

State religion in Nepal was based on the royal lineage's religious practices, and only this lineage was accorded the power to offer patronage and confer state status to the state rituals. This basic notion has also proved extremely resilient and can be discerned in the contradiction (to be debated in a later subsection) between the 1990 Constitution's stress on the one side of a sovereign Hindu monarch and descendants from the Shah lineage's exclusive right to the kingship, and on the other side, a multi-ethnic and religiously diverse state. This contradiction was sought solved at the supra-structural level by the recently (in April 2006) reinstated House of Representatives, which claimed itself sovereign and abolished Hinduism as state religion and cut deeply most of the privileges of the kingship.

With the adoption of the Hindu notion of the king as epitomising society and hence the embodiment of his subjects, it was natural that 
sarkar referred both to the govemment and the king as the embodiment of his subjects. While the more subtle interpretation of the founder warrior king's treatise Divine Teaching (Dibya Upadesh) remains contested, the fact that the founding statement of Nepal as a Hindu kingdom, a garden of four classes (varnas) and of 36 castes (jats) was even incorporated into the democratic 1990 Constitution is worth reflecting upon (see Sharma, 1997). ${ }^{7}$ As we will see below, the cultural model of the monarchy as Hindu has delivered a main state-defining feature that has proved extremely compelling in Nepalese society. This model, expressed and legitimised in state rituals, remained virtually uncontested until the 1920 s when, as we will later see, some small societies started to question the legitimate basis for the kingship's divine rule and the hierarchical caste order.

Closely linked to the Shahs' assimilationist and conciliatory strategies in relation to tribal religion, they also opted for a policy of selective integration of local lords and nobles and chiefly lines from the heartland into the state apparatus. The same heartland (the western and mid-western hills) was to become the core area of Maoist resistance in the late twentieth century.

\section{The Consolidated Hindu State: The Rana Era (1846-1951)}

Jung Bahadur of Kunwar asserted himself as a seminal figure in Nepalese political history through the Kot massacre in 1846. By means of the famous royal sanad (charter), he managed in 1856 to curtail the de facto authority of the Shah patrilineage of succession and established his own patrilineage (adopting the title of Rana) as the heirs ${ }^{8}$ to the Premiership, which were accorded extremely wide powers (see Uprety, 1992: 3-4). ${ }^{9}$ Rama rule thrived during the next nearly 100 years within the already well-established institution of divine kingship. The king as the sovereign was the supreme dispenser of land and offices amongst others. He was the patron of an extensive pyramid-like ritual exchange network $^{10}$ as well as the head of command structures and of direct/ indirect political control of remote areas, also exercising dominion over a centralised taxation system (based on a particular land tenure regime) in addition to monopoly trade. The centre of judicial, legislative and executive powers was the Maharaja and his Council, who appointed and commanded the district officers (badahakims). The Ranas centralised the bureaucracy even more than during the rule of the Shahs. Even minor appointments needed the Premier's approval. A rule of annual renewal of offices from lower-ranking offices up to Commander-in-Chief ensured a strict upward "accountability system" based on loyalty in exchange for patronage. This principle was matched by a principle of hereditary succession to all major civil and military positions. The state apparatus was thus grounded in a bureaucratic culture defined by a patronage system that mobilised both kinship and caste principles.

The official state realm was devoid of the Western distinction between the public and the private. At the very top was the Premier, who after 1856 substituted in persona the erstwhile king as the head of government (sarkar) and thus as the embodiment of all matters of collective interest. In other words, the Ranas ruled and the Shahs reigned. The idea of a harmonious, hierarchical order between ruler and subjects co-existed uneasily with the ruling family's violent intra-family feuds over the right of succession to the position of Premier. Of the ten Rana Premiers, only four died natural deaths while in office. The others were either assassinated or forced to abdicate (see Uprety 1992:5). The hierarchical order was also formalised through the promulgation in 1854 of the first civil code, Muluki Ain. The promulgation of a civil code was inspired by the rulers' exposure to the British Empire's use of codifications. The content of the code represented an ambitious, yet pragmatic effort to superimpose an orthodox Hindu caste structure based on the idea of castes as qualitative species, some slaveable and other unslaveable. Any notion of the individual was subsumed under the concept of the collective as an ascribed category of caste. One outstanding feature of the Code's pragmatic attitude is the middle position conferred to tribal groups, which the Code ranked as pure castes, both subdivided into slaveable and unslaveable." This very substantial reform is an early precursor to political reforms by successive generations of authoritarian rulers in Nepal. Certain formal features are borrowed from Western institutions and political language and wedded with political notions and practices of the Hindu state, regardless of whether these were truly rooted in Nepali society or simply imposed through combining force with more subtle forms of coercion. 
The pragmatic alliance with the white, impure masters on Indian soil allowed the Ranas to pursue a foreign policy of strict isolation. This policy suited well the central nation-building objective of reinforcing a notion of Nepal as a unique nation of the ritually pure. In addition, the policy — whether intentionally or not - practically isolated the elite and the subjugated multi-ethnic population and lower castes from direct exposure to 200 years of dramatic political upheavals that led eventually to political and industrial revolutions in the Western world. ${ }^{12}$ The full impact of this isolationist policy is impossible to spell out in any satisfactory manner here, but the implications for political imaginations of govemance and economic development seem noticeable even until very recently.

The end of the Rana period has been characterised by contemporary and later commentators as the end of conspiratorial violent politics in Nepal. But the exceptionally unclear circumstances surrounding the assassination of the royal couple and their nearest kin in June 2001 do not make it unreasonable to question whether this conclusion is premature. The political culture (institutionalised for more than 150 years of Shah and Rana rule) with its underlying models of the public order, of centralised Hindu state religion, and of loyalty based on patronage and favouritism would also prove very resilient against later efforts to reform the polity from above.

\section{THE RESTRUCTURED HINDU STATE IN THE TWENTIETH \\ CENTURY}

\section{The Early Post-Rana Period}

The formal ending of Rana rule in Nepal was due to a particular circumstantial constellation of global, regional and domestic conditions. The recruitment of Gurkhas ${ }^{13}$ into the British Indian Army led to a simmering political consciousness about the political regime in Nepal. The Gurkha's participation in the two World Wars, and their stationing in India during the most decisive years of the Indian Nationalist Movement, was of particular importance for their earliest political conscientisation. After they were pensioned, a not insignificant number of Gurkhas refused, partly on political grounds, to resettle in Nepal. In addition to the ex-Gurkhas, a small number of elite intellectuals who stayed in India due to family connections and higher studies were also groomed politically in the Nationalist Movement. They came to form the core of the small anti-Rana groups. The victory of the Liberation Movement in 1947, the subsequent withdrawal of the British and the instalment of the first post-independence govemment created a new political situation in Nepal. The Ranas were deprived of their old colonial ally and found themselves with a neighbouring government which had every reason to dislike the Ranas, who through the supply of Gurkha soldiers had directly helped the British to maintain their empire. Internal dissent over succession in the rapidly expanding Rana family helped to weaken the Ranas' ability to close the ranks in this new international situation (see Uprety 1992:5).

While some anti-Rana activities had already taken place in India in the $1920 \mathrm{~s}$ and $1930 \mathrm{~s},{ }^{14}$ the $1940 \mathrm{~s}$ brought a rapid growth in political activity, which included one assassination attempt. This was discovered. Some of those implicated were punished by execution and thereby became the first martyrs for the democratic cause. In the late 1940 s the Nepali National Congress and the Communist Party of Nepal were formed. When Nepal experienced its first incipient civil disobedience movement, the erstwhile Rana Prime Minister found it necessary to undertake some limited reforms ${ }^{15}$ so as to cope in the new international situation. These steps generated an intemal backlash, leading to the resignation of the Prime Minister (Padma Shamsher) and a ban on the recently formed Nepali Congress Party. To appease the new Indian government, the Ranas let the Indians use Nepalese troops during the Hyderabad and Kashmir crisis and accepted, in 1950, a Treaty on Trade and Commerce and another on Peace and Friendship (see Shaha, 1990b:195). The latter treaty made Nepal an integrated part of India's security policy. The Trade Treaty opened Nepal up for Indian economic interests on very unequal terms and laid the basis for a growing Indian domination of the Nepalese economy in the 1960s and 1970s, with profound long-term consequences for Nepal's subsistence economy and the poverty situation. With the influx of industrial goods like manufactured cloth (augmented later in the 1960 s by farm implements and household utensils), the artisan and service occupations of Nepal's numerically large service castes were undermined. Also, the import of Indian food items, such as a large variety of spices and salt (the salt trade 
with Tibet was made impossible by the Chinese occupation in 1959), altered the viability of particular occupations and economic institutions amongst some of the ethnic groups.

Already in 1951, the Communist Party for the first time demanded the drafting of a new constitution by a constituent assembly. This demand was voiced during the following 50 years by a number of communist actors, including the current Communist Party of Nepal (Maoist), which waged a war against the "semi-feudal" state until 2006. ${ }^{16}$

The actual significance of the Shah royal family in anti-Rana activities in the 1930s, 1940s and in the Ranas' ultimate downfall in 1950 is disputed (see Shrestha, 1984:121; Brown, 1996:14-22). In November 1950 , the king and other royal family members sought asylum at the Indian embassy in Kathmandu. The royals were later flown to India. The circumstances surrounding the royal family's flight reveal both India's direct and indirect roles in the ousting of the Ranas' rule. As we will repeatedly observe over the next five decades, India was ambivalent in its strategic postures towards its northern neighbour. The Congress's armed resistance movement, Mukti Sena, ${ }^{17}$ received only limited support from the Indians, who feared the immediate effects of an unstable northern frontier however much they wanted a more palatable rule in Nepal (Rose 1971). ${ }^{18}$ Delhi doubted the Congress's capability as a prospective ruling party, and feared the Congress's collaboration with the Nepali Communist Party at the time of the communist takeover in China. Consequently, they went for a carefully guided transition based on a socalled power-sharing arrangement through a coalition government of the Ranas, the kingship and the Congress (see Rose 1971:194).

The Delhi Settlement of 1951 was largely formed by Delhi's pragmatic strategic interest. The Settlement, or Delhi Compromise as it was also called, can only be said to have been a compromise of a cosmetic kind, since the Congress was mostly excluded from the real political negotiations. There was certainly a reshuffling of the powersharing arrangements between the Shah family and the Rana family. Somewhat more political power was yielded to the kingship and the king in persona, whilst the Ranas' dominance within the palace administration and the army was mostly left intact. The consequence of the Delhi Compromise could be seen as highly influential for the political development in Nepal until the present. The autocratic state centred on the institution of kingship was largely left intact. The term "intact" is purposely used here to underline the fact that the institution of kingship as a form of reign could survive a century of Rana political "footbinding". The Ranas very cleverly did not interfere with the traditional and effective modes of publicising and exercising kingly authority through patronage of a number of national religious festivals and temple institutions situated both in the capital valley and throughout the rugged countryside (see Bleie and Bhattarai, 2002).

After the Delhi Settlement, the Congress's room for manoeuvre to bargain for any real democratisation was severely limited. The regime was, in other words, intact. Only the partly co-opted and inexperienced Congress Party gave the new government an aura of democratic legitimacy. The Delhi Settlement was largely made by Indian actors in New Delhi, some of whom had multiple economic, kinship-based and ideological links to the Shah and Rana contenders. The "compromise" provided new political capital to the king, who could return to Kathmandu in triumph, declaring his commitment to building democracy in Nepal.

This Royal Declaration, like later political statements from Congress politicians, was of a rhetorical nature. The composition of the old elite was intact. The practice of marriage alliances between the Shahs and the Ranas continued, as did the customary patronage practices of giving positions within the bureaucracy to clients, kinsmen and other allies. Though some of the traditional privileges and power bases of the Ranas and Shahs were undermined or abolished outright, they successfully expanded into new sectors of the Indian and Nepalese economies. $^{19}$ The India-groomed Congress, superficially victorious, actually lacked a popular countrywide support base and proved itself incapable of bringing the Kathmandu-based anti-Rana intellectuals into the party echelons (see Joshi \& Rose, 1966:123-124). The Koirala brothers were in the top leadership. B. P. Koirala wanted a real dismantling of the Rana state, while M. P. Koirala had strong royalist leanings. M. P. Koirala is representative of the great majority of the 1950 s generation of leadership which was accultured in India and had internalised the Sanscritic world view of divine kingship and a 
hierarchcial social order of rulers and ruled. Neither the palace administration nor the incipient bureaucracy, or any other central social or political institutions, nurtured cultural ideas and practices which could act as catalysts toward a democratic political culture. To be sure, political statements could be heard that carried a new aura of liberal political aspirations. But neglecting to initiate anything akin to modern partybuilding from grass-roots constituencies, the newly groomed Congress leaders and aspiring leaders resorted to traditional modes of patronage and political decision-making which suited the invigorated kingship very well. The outcome was an empowered king who the Congress hoped would be a balancing agent against disgruntled Rana elements. The king and his courtiers had more ambitious intentions than the Congress hoped, and they succeeded in acquiring considerable power over the indecisive and disunited party.

This set of developments led to a series of short-lived governments bent on internal rivalries, unchecked by any popular party-based or electoral accountability. The king appointed M. P. Koirala to the position as Prime Minister twice in 1952/53. Both this and other offices were handed out as gestures of royal benevolence and patronage, not as appointments based on any popular mandate. Benefiting individuals in their tum became empowered and capacitated to dispense their own extended patronage. During this period, the traditional elite formed their own pressure groups. The Communist Party was banned in 1955. The party continued underground to influence some permitted civil rights organisations and, more importantly, it started to build a cadre base in some parts of the western and eastern hills. In these western hills (Pyuthan, Rolpa and Rukum), the Maoist insurgency would start about five decades later. Already in those early years of party-building, the communists were ideologically divided over the role of the monarchy in Nepal (Brown, 1996:27)

As the king expanded his power base and the array of short-lived governments provoked disillusionment with so-called democracy, the king abandoned his promise of a constituent assembly and in 1954 proclaimed that supreme power was to be vested with the kingship (see Shaha, 1990:303-305). These moves between 1951 and 1953 have certain parallels with the 1991-1999 period (see discussion below). The
1955 successor to the throne, King Mahendra, was bent on consolidating monarchical absolutism. The elections promoted earlier were postponed and the administration reorganised to facilitate the ambitious monarch's direct control and patronage. ${ }^{20}$

During the post-Rana period, novel avenues for political careers opened up. The new build-up of bureaucratic institutions, also aided by the influx of development funds, resulted in an increase in both political and bureaucratic offices. ${ }^{21}$ This led to new opportunistic competition for offices and influence. Also during this period, Indian influence and to some degree outright interference in domestic affairs continued and inevitably provoked growing anti-Indian sentiment. To provide a thin façade of democratisation, the ban on the Communist Party was lifted in 1956. This lifting paved the way for a joint campaign with the Congress for elections. After years of internal scrambles, the Congress managed in 1956 to consolidate a socialist platform. Despite the parties' successful pressure for an election, they were not able to stop the king from promulgating a new constitution directly and dishonouring the demand for a constituent assembly. The new 1959 Constitution vested all juridical and executive power in the king. Nevertheless, the appointment of the experienced B. P. Koirala on the basis of the 1959 elections led to a brief period of incipient democratisation under Koirala's unifying leadership.

\section{The Aborted Democratisation under B. P. Koirala}

B. P. Koirala's appointment was a pragmatic compromise, but the palace's cool reception shifted to staunch resistance when the king felt threatened by the emerging prospect of new, Western (democratic) accountability structures based on an elected parliament. During this phase, the communists (who took a strong pro-Chinese stand) led a fairly effective opposition in the parliament (see Brown, 1996:34). The B. P. Koirala government, with its recently adopted socialist programme, started promoting the concept of an interventionist state which should deliver basic services, run economic enterprises and uphold an independent judiciary. This new programme led to certain land reforms and to an early effort to institute an independent judiciary. The Koirala 
government mostly succeeded in the precarious balancing act of maintaining fairly good Indo-Nepali and Sino-Nepali relations. ${ }^{22}$

The not insignificant gains of the B. P. Koirala government during its early period gave Koirala a growing popularity and authority. The government's early effort to institutionalise a more independent bureaucracy threatened to marginalise the palace-based administration and the traditional patronage-based politics (See Joshi and Rose, 1966:386; Rose and Scholz, 1989:48). In December 1960, the Prime Minister and his cabinet were arrested. The constitution was suspended and direct palace-based rule instituted. The conspicuous lack of public resistance from the smaller parties, the traditional elite and the upper echelons of the bureaucracy against the royal ousting of an elected government shows just how profoundly the patronage-based political culture permeated these public institutions. Also importantly, the intemational community did not strongly condemn King Mahendra's move. The ousting of the government and the ban on the party led Congress members to start a resistance movement in India. This movement could not muster enough support for conducting raids on Nepal's soil that would represent any real military challenge to the regime. The Indian endorsement of the insurgent activities on their side of the border was soon withdrawn, on account of the Sino-Indian border conflict in particular, which altered Himalayan geopolitics.

During the 1950s and the first years of the 1960s, the monarchy quite effectively managed to manipulate and contain the incipient seeds of democratic transition. With some level of credibility, the king could denounce parliamentary democracy as a foreign import. Instead, the monarch announced the establishment of the four-tiered Panchayat system (underpinned by a new constitution), which he claimed would be based on Nepalese political culture. ${ }^{23}$ In addition, the regime - inspired both by Maoist ideology and by the Nepalese notion of unity in the public order - instituted class organisations (bargiya sangathan) for farmers, women, youth and former servicemen. These organisations were seen as representing private interest groups which were entitled to nominate some representatives to the National Assembly. ${ }^{24}$ Other private interest organisations needed government approval to enter public space or were banned altogether (i.e., the communists) from the same space.
As Burghart (1994:1-14) has pinpointed, the 1962 Constitution contains a striking contradiction. On the one hand, it was to constitute political relations between the king and his people in harmony with the traditional order. On the other hand, the constitution was a modern legal means by which a remoulded political culture was to be created. The Panchayat system represented certain novel organisational forms (such as the class-based organisations ${ }^{25}$ ), but tapped into and expanded local and supra-local traditional forms of political authority favouring men from the highest castes. Local and central public arenas revolved around chains of chiefly and royal authority. The Rana-instituted governance practice of mobile official tours (daudaha) was revived. The monarch held annual audiences (darshan) in the zonal and district centres and accepted sulami, the ritual offering (similar to the offering of gifts to deities in temples) of a coin to the royal authority in appreciation for being appointed to a public office. ${ }^{26}$ The practice of pajani, the annual renewal of offices, was also given new emphasis by the royal authority. These public practices were also expressive of the royals' full control over any legitimate expression of public service. ${ }^{27}$

All these engagements were guided by a notion of public order defined through unity, ultimately vested in the institution of kingship. This notion was different from the Western notion of public order as a negotiating space for diverse, partly conflicting, partly converging personal interests. Thus, in Nepal dissent and conflict were by and large not permitted.

Nation-building efforts (desa banaune) during the Panchayat years showed how contested and incomplete the project was. A language policy issue such as the role of regional languages in education and mass communication was highly contested already in the 1950s. This and other language issues reappeared soon in political dehate. In 1962, Nepali was made the sole medium of instruction in all state schools, and broadcasts in Hindi and Newari were terminated on Radio Nepal in $1965 .{ }^{28}$ By a combination of statistical and rhetorical means, Nepali was made the only official language and the Nepalese, claimed to be "one people".

Similar means were used to construct the common religious identity the Hindu kingship needed for its legitimate reign. A notion of the Hindu nation could be forged by manipulating the number of Hindus in the 
1961 Census. As an accommodation to international human rights norms, the state officially abolished the caste system. The regime thus had to resort to the vague claim of being the defender of "local tradition". Undoubtedly, such a stance indirectly lent legitimacy to the still entrenched caste system, which the same regime had recently officially abolished.

While some progressive reforms were enshrined in policies and the 1962 Constitution, ${ }^{29}$ and the somewhat reformed governance system gave the appearance of separated executive, judicial and legislative branches, appointments and promotions and dismissals were handled by the expanded sovereign authority of the king. As Hayes has noted (See Hayes, 1975:616-628), the monarch skilfully managed to combine tapping two sources of legitimacy, the traditional Hindu kingly authority and the Western notions of representative democracy. Direct elections were only held at the village assembly level. Here the segments of the population with high ritual status and landed property dominated the assemblies. If popular accountability at that level was variable, it was minimal at higher levels of the indirectly elective system. At the centre, the parliament endorsed formally decisions already made by the Central Secretariat - the apex of royal authority. As comprehensive civil liberties were forbidden, the regime committed human rights violations. However, the ruler's alliance-building and patronage of the police, army and rural and urban elites was successful towards preventing excessive direct use of violent oppression. Internal criticism within the system was contained by intermittently approving certain minor reorganisations. The expanding middle class was kept politically inactive by providing its members with new economic opportunities that also gave social status. Of principal importance were job opportunities within the government and the aid sector, which started to grow in the 1960s and virtually exploded in the following two decades. The disillusioned and exiled Congress experienced in the 1960 s a considerable stream of defections; many entered the ranks of the Panchayat institutions, indicating their opportunistic power-seeking motivations. ${ }^{30}$

Opportunism towards being able to rule and divide also characterised the royal authority's official and unofficial dealings with the banned leftist parties in this period. The communists (divided into
pro-Beijing and pro-Moscow factions) were not considered as real a contender for power as was the Congress. The Beijing faction was thus assisted in order to undermine the Congress's support-base. The Panchayat regime also received considerable aid from the Maoist Chinese regime. As the communists gained in influence, the palace shifted sides and started to be more liberal to the Congress. Amongst others, political prisoners (including the aging and ailing B. P. Koirala) were released. The 1971 elections to the Panchayat and class organisations showed popular discontent with the system (Brown, 1996:50). Moreover, Himalayan geopolitics again changed in the 1970s as communist China's international position became weaker. The king, who had considered the Chinese regime his closest ally, increasingly had to recognise that his southern neighbour was a contender for the position as a regional superpower.

\section{The Middle and Late Panchayat Period}

During the late Panchayat period, the hierarchical social structure underwent certain changes, but without offering opportunities for upward mobility for individual women or for individuals from the previous untouchable castes and most of the ethnic groups. The mechanisms for upward mobility and incipient class formation were based on formal education, particularly favouring Brahmin men with proper command over a Sanskritised Nepali. The new employment opportunities in the government were snatched not only by Brahmins, but also by Chhetri and Newari men - all from caste groups from the hill region which had earlier dominated the bureaucracy.

Since the bureaucracy in the 1970 s and 1980 s also expanded very rapidly at local levels, it gave ill-informed outsiders the impression of an increasingly decentralised administration with enhanced capacity to function as a redistributive state apparatus. The expansion of govemment offices at regional, zone and district levels was changing state-society relations, but not in a manner conducive to democratic constitutional notions of impartibility, separation of the three cardinal functions of government and of local self-governance. Instead, donor-dependent growth let to an unprecedented expansion of the centralised patrimonial state, within which the extra-constitutional political centre (the Central 
Palace Secretariat) demanded loyalty from the upper echelons of a satellite-like and steadily growing bureaucracy. High caste patronage culture, consisting of a complex set of behavioural codes and practices including favouritism and "bribery", was extended down to the lower grades of civil servants and outwards to the newly formed rural administrative tiers. In the 1980 s, a court dialect used by the Rana aristocracy in the previous century on social occasions was the routine form of address among civil servants when signalling and negotiating status and role expectations (see Pandey, 1989:326).

The Palace Secretariat had managed to get a constitutional basis for their control over all policy decisions. ${ }^{31}$ This was a fateful structural incongruity which crippled proactive policy-making and implementation from the level of ministers down to top bureaucrats and below, as all were vulnerable to arbitrary dismissal not on grounds of incompetence but because of either a failure to show sufficient loyalty (chakari) or the top patrons' shifting alliances and subsequent changes of incumbents. The rapid influx of aid money into such a patronage-based usury system led to a redefinition of the well-established and morally accepted system of "bribery" and chakari as well as to increased outright embezzlement of funds. ${ }^{32}$

The rapid and soon heavy dependence on donor aid (especially bilateral aid), which in this period covered not only a substantial portion of development expenditure but also the state's administrative expenses, created a new category of patrons. These external Western patrons had their own notions of good governance and accountability structures which the ruling Nepali politicians and bureaucrats had to please. The accommodation of two outrightly different political notions and institutional practices, one inner life based on age-old notions of dispensing patronage in exchange for loyalty by personalised idioms and one outer life for the donor community and the international community, necessitated a sophisticated art of impression management and (self) deception. Administrative reforms, including a number of technical assistance programmes, were enacted but, to the dismay of the donors, with limited effects on the efficiency and quality of the administration, its service delivery and development efforts. Ironically, the Palace Secretariat, the centre of political power and the chief producer of the caste and patronage-based values and governing style, was overlooked in these reform efforts. ${ }^{33}$ The very structure and function of the administrative and political system operated according to very different "unwritten" institutional rules, which I have briefly described and analysed above. In order to accommodate the donors' urgings for results, another strategy for quasi-solution of the administrative impasse was the establishment of parallel institutions (such as Development Boards), which had their own rules, regulations and salary structure.

In the 1970 s, it was all too evident that the much-debated and longawaited land reform (enacted in 1964) had done little to change the inequalities in size of landholdings (see Zaman, 1992; Riedinger, 1993). In the hills, the growing livelihood crisis $^{34}$ was, to some degree, mitigated by migration to the low-lying fertile Terai. This plain region had become a malaria-free zone with American aid. The state's biased land allotment policy and resettlement schemes in the Terai led to a reproduction of the hills upper-caste social order in the Terai (Shrestha and Conway, 1985). Temporary migration to India and to the cities also acted as safety valves in the crisis-ridden hill communities. The donorfinanced construstion of some roads starting in the 1960 s and continuing in the 1970s facilitated a rapid influx of Indian manufactured goods. This led in the first place to the rapid expansion of rural markets thriving on selling manufactured goods and then to urbanisation, mainly in the Terai and in Pokhara and Kathmandu valley. These developments then affected the social structure, undermining the traditional interdependency between the service castes and high castes. Since no alternative state-sponsored social safety net was in place, and caste discrimination still barred these people from entering the expanding and profitable non-agricultural sector, their livelihood situation deteriorated further. As smallholders, these sections (whose composition in terms of ethnic affiliation and caste status varied considerably) had marginal access to the material rewards from the large and mostly bilaterally financed development projects, such as the USAID Rapti Zone Integrated Development Project. Both the rhetoric of "a right to development" and "poverty alleviation" espoused by these development agents, as well as "class-based justice" articulated by the communists sowed the early seeds of what would ferment in the 1980 s and 1990s into a widespread subjective political consciousness of grievance and relative deprivation. The Maoist rebellion would come to 
start from some of the districts under the Rapti Zone (Rolpa, Rukum and Pyuthan).

The new King Birendra, in spite of his Western elite education, continued his predecessor's authoritarian political line. The Congress remained banned and the leaders exiled. The precariously forged unity was disturbed by a number of violent attacks, ${ }^{35}$ the most consequential in retrospect being the Jhapa Uprising in 1971. The uprising showed the regional link of the outlawed Maoist Communist Party to the Communist Party of India (Marxist), which started the Naxalite movements in Bihar and West Bengal. Only the border river Mechi separates Jhapa from the epicentre of the movement, Naxalbari. The Naxalites' practice of socalled revolutionary justice was taken up by young Jhapa activists, and some local landlords were murdered in the way of executions. While the uprising was brutally quelled by the government, it was politically mobilising and led to the formation in Jhapa of the All Nepal Communist Coordination Committee, which started forming local groups. Such class justice came more than 20 years later, to be taken up on a large scale by the Maoist Movement.

During the deteriorating political situation under Indira Gandhi, the exiled B. P. Koirala (then President of the Nepali Congress) retumed to Nepal in a proclaimed effort to contribute to national reconciliation after India's threatening (with Nepalese eyes) annexation of the Himalayan kingdom Sikkim in 1975. Koirala's cult-like position was not sufficient political capital for any revitalisation of the party, though there was some opposition to the regime. The execution of Pakistan's Prime Minister Zulfikar Ali Bhutto was an opportune catalyst for public demonstrations, again shattering the precariously forged unity of public life. The spreading demonstrations were also indirectly protests against the execution of the persons convicted for the assassination attempt on Birendra a few years earlier. This spontaneous unrest led the royal authority to proclaim a referendum to decide the future of the Panchayat system. The referendum in May 1980 resulted in a small but significant majority voting in favour of the Panchayat system. The result may be interpreted as the outcome of pragmatic support for a reformed Panchayat system, a lack of trust in the political parties and the panchas' massive economic expenditure to promote their campaign. In addition, the Congress and the communists failed to see the importance of building an inter-party alliance to win the referendum (see Brown, 1996:91).

B. P. Koirala's disastrously poor judgement during his final years, which nevertheless did not lead to his removal as elected leader, shows how strong the culture of respect towards elders continued to be in the political domain. This culture would, as we shall see again, become conspicuous as we move to consider the Congress leadership of the 1990s.

Between 1983 and 1990, the Nepalese communist movement was riddled by ideological differences and personality-based conflict. ${ }^{36}$ The movement and its ideological debates and struggles occurred in India, where many of the activists worked and studied.

As Brown among others has pointed out, there was a confined political liberalisation after the 1980 referendum. Among the reform measures were election of the Prime Minister by the National Assembly and the introduction of the adult franchise. But these measures were accompanied by an expansion of the royal authority's extraconstitutional sources of power. ${ }^{37}$

The inadequate understanding by the powerful donor community in Nepal of state-society relations and its reductionist perception of good governance as a matter of reforms and building technical capacity, and poverty as a result of demographic explosion causing an environmental crisis, diverted attention away from the two critically interdependent core issues. These were (1) the elite's centralised control of the state apparatus, and (2) the distributional aspects of the poverty issue. The latter issue would have put land reform and the management of water and other bio-resources centre stage (World Bank, 1988).

While the political pressure increased during the 1980 s, the overall livelihood situation remained poor. According to a conservative World Bank estimate, about 50 percent of the population faced chronic or seasonal food deficits (World Bank, 1991), and a very large proportion of the children were stunted. Regional imbalances in food production and life expectancy were also considerable (World Bank, 1990). Gender discrimination remained pervasive, as Nepali women remained among the most overworked, undervalued and politically excluded of all the 
world's women - despite more than a decade of women-targeted policies and programmes.

\section{THE DEMOCRATIC CHALLENGE TO THE HINDU STATE}

\section{People's Rebellion: The Seeds of a Revolution Betrayed}

In late 1989, the controversy over the Indo-Nepali Trade and Transit Treaty was unresolved. The urban population in particular felt the repercussions of the dispute and the ensuing trade boycott. Incorporated into the global electronic news network, the Nepalese received radio and television news about how people's power in Eastern Europe could overthrow oppressive dictatorships. People's imaginations were receptive to these media-sent ideological messages ${ }^{38}$ The Nepalese audience could also observe through the international media how people could concretely organise for political change. In early 1990, a loose alignment was established by a bloc named the United Left Front (ULF), composed of seven leftist parties, and the Congress Party. ${ }^{39} \mathrm{~A}$ number of other small leftist parties decided at this stage of fight separately, but in collusion with the Congress and ULF. The anti-regime protests (Jana Andolan 1) started on a highly symbolic and official day, Nepal's Democracy Day, 18 February.

The outburst of increasing crowds of agitators in a public domain based on a model of harmony and consensus was first met by the regime with a certain degree of repression. The regime also resorted to the wellknown recipe of undermining (the movement's) credibility by playing on anti-Indian sentiments. Limited concessions were not considered at this stage. During the build-up and climactic stages of the movement, the police violated not only human rights but also indigenous moral codes of conduct, leading to stronger anti-government reactions. ${ }^{40}$ The protests initially grew and waned. Then the demonstrations grew in spurts as the protests spread to all the towns of Kathmandu Valley and later to the towns in the Terai, culminating in bloody confrontations with the police in April. Alongside a curfew, the monarch gave some concessions, such as lifting the ban on political parties.

The nearly exclusive urban and mostly middle-class foundation of the protest movement, no doubt mirroring the centralised nature of state power in Nepal, would prove to have major consequences for the outcome of the movement. As it grew and the regime's oppressive apparatus was felt not only by more people but by new types of demonstrators (including educated professionals not accustomed to face direct brutal repression), anti-royalist attitudes gained ground. ${ }^{41}$ As Brown among others has argued, the widely circulated accounts claiming that the well-meaning King Birendra was manipulated during those critical weeks by his courtiers are highly dubious. The king and his inner circle of advisors must to some extent have underestimated the popular momentum of the movement. ${ }^{42}$ Following the climax of bloody clashes caused by indiscriminate firing by the security forces on 6 April, the palace, for reasons not fully known, did not opt for a major clampdown by the well-equipped and royalist army. Instead, the regime opted for a negotiated "compromise".

The sets of conditions that led the leadership of the Congress-ULF alliance to opt for a compromise are too complex to be given proper scrutiny here. Congress and communist activists shared common experiences of exile, imprisonment, insurgency and unpredictable palace politics. Nevertheless, the alliance was frail from the start and was riddled with ideological and personal differences, disparate party cultures and varying credibility in royal and international circles. The Nepali Congress had a history beyond that of a banned opposition party. It had in certain periods been a partner-in-government (see the above political history between 1951-1990). Therefore, the palace saw the Congress as a more obvious negotiating partner than the more overtly anti-monarchist leftist parties in the alliance.

At that time, the outrightly anti-monarchist leftist parties which had not joined ULF started to play an increasingly prominent role in the rebellion. It showed signs of momentum as a mass movement with a broadening support base. These developments worried leading Congress activists who were royalists and had no ambition to let loose a revolution that would dismantle the entire power structure of Nepalese society.

The popular mass demonstrations gained momentum in a public domain structured on a model of non-dissent and the unifying unique person of the king. However, at this moment no full-fledged political programme for democratic transition from an absolute monarchy to a responsive, pluralist secular state was worked out. Such basic neglect 
would prove very influential indeed. Without such a political programme, one on an ad hoc basis instead relied on slogan-like claims for a constitutional monarchy and electoral democracy. This ad hoc strategy revealed more fundamental shortcomings of the lead party of the United Left Front, Nepali Congress, party's organisation and culture. Its organisational culture was based on principles of patronage, respect for seniority, caste status and opportunism. Elections to leading offices were not based on any proper democratic accountability structure and rules, which were so basic to a cadre-based party culture. With many of the senior Congress politicians under arest, the second layer of leaders, who had not been permitted to gain solid political experience by their detained patrons, found themselves suddenly in charge of the challenging task of steering an escalating movement in collaboration with the more militant and experienced communists. This created alarm among both the aspiring leadership as well as the senior Congress leaders. Without consultation with the communist leaders, the Congress leaders brokered the compromise with the palace.

As noted, the very outburst of and organisational form of the People's Movement reveals Nepal's recent integration into a globalised electronic network. The international media's subsequent reporting of the movement helped create some degree of international support and a certain pressure on the government. The diplomatic community in Nepal also exerted pressure on the discredited government and maintained contact with the ULF. Some diplomatic missions seem to have specifically engaged themselves. According to Brown, US officials actively encouraged Congress leaders to reach a compromise with the palace that included the establishment of a constitutional monarchy in order to contain the growing leftist influence in Nepal. ${ }^{43}$ The American position was again reiterated in strong language when the Congress Party supremo Ganesh Man Singh visited the Bush administration in December 1990 in order to muster support (see Thapa and Sinjapati, 2003:36).

The relative importance of other intemational, albeit regional actors is more difficult to assess. The Indian coalition government as internally divided on this issue. One of the coalition partners, Janata Dal, had for quite some time been supportive of pro-democratic forces in Nepal. The religious Bharatiya Janata Party was a strong supporter of the Hindu monarchy. In order to balance these opposing stances, the government officially stressed a policy of a middle course, but this official posture may not represent the entire picture. ${ }^{44}$

The compromise prevented Jana Andolan from becoming a national movement, supported by the country's oppressed population of small peasants, low castes, many of the ethnic communities, and rural women. More conservative political leaders with loyalist inclinations hoped the deal would give them full access to the state through new political channels. To them a compromise with the old regime, however opportunist, patronage-ridden and anti-democratic, appeared to be a much safer solution than an unpredictable alliance with the more extremist left groups, which wanted a new social order and a "new state".

The April bloodshed and deal brokered was followed by the establishment of an interim government and a period of prolonged negotiations between the newly elected leaders, political parties and palace. The new government ${ }^{45}$ was to lead the nation through a difficult transitional period, during which democratic legislation would be formulated, a free press created, general elections held and the volatile law and order situation controlled. In addition, the new coalition cabinet promised to curb corruption and to strengthen the judiciary which was asked to investigate human rights abuses during the Jana Andolan. The cabinet also promised to start redressing discrimination against women and ethnic communities. The agenda was, in other words, tall indeed, and included many of the grievances voiced by the more radical sections of the Jana Andolan.

During the following months, the interim government showed a limited ability to follow its own directives, provoking strong criticism from the more radical sections of the UPF and civil society. This lack of political ability - perhaps also of will - revealed the highly problematic terms of the "compromise" with the regime, a concession which leading actors within the donor community in Nepal actively supported. The aid community in Nepal at that time predominantly held a neo-liberal understanding of a lean(er) Nepalese state in addition to a greater role for the market and civil society actors, in order to generate growth. They were, therefore, unreceptive to the left's political programme of dismantling the elite's parasitic grip on the state by instituting republican 
rule, which could have cleared the ground for an active redistributive state that could intervene with the market forces. It remains uncertain whether the donor community fully contemplated the regime-conserving and conflict-escalating impact of their stance.

The old regime was more or less intact. Yet, some of its supporting pillars showed signs of fracturing. The political establishment was divided over the need for political reforms, hardliner panchas stood against liberal panchas (with Congress sympathies). They were nevertheless still unitedly opposed to any radical legislation that could threaten the interests of the old elite and the middle class. The Congress leaders, including the Interim Prime Minister, saw the institution of monarchy as the very essence of the Nepalese nation and believed that it was possible to steer a transition from an absolute to a constitutional monarchy (see Brown 1996:147-149). In order to try to save whatever could be saved of the legitimacy of King Birendra and to shore up the institution of monarchy, no legal action was taken against the senior civil and police officials whom two human rights commissions held ultimately responsible for the human rights abuses during the Panchayat and the Jana Andolan. ${ }^{46}$

The culturally unquestioned belief in the Hindu monarchy, resulting in a fear of strong influence from the republican left, might largely explain the Congress's and other leading stakeholders' rejection of the demand for a constituent assembly to draw up the new constitution. As shown above, this demand has repeatedly been raised by the communists since they first formed the party. We will come back below to why this demand was to become probably the main reason for the Maoists' withdrawal from the final rounds of negotiations in both 2001 and 2003

\section{The Contradictions in the 1990 Constitution}

Different versions of the new constitution were drafted, showing the ongoing struggle between the king's unwavering will to remain the source of sovereignty and the democratic alliance. ${ }^{47}$ The commission also invited inputs from the political parties and the general public and sent a lawyer to study other relevant cases of constitutional monarchy. The majority of suggestions concerned regional, religious, linguistic, gender and ethnic issues; in other words, issues of how to accommodate differences into a state monopolised by the high caste men for centuries. The commission and the government chose largely to overlook these suggestions, denouncing them as a threat to the nation state's unity. The leader of the commission, Justice Bishwanath Upadhayaya, characterised most of them as "unfortunate" and "peripheral" issues that revealed the general lack of constitutional knowledge among the citizenry (Hutt, 1994:36).

The 1990 Constitution, as will be discussed below, represents in some respects a real advance compared to the earlier constitutions, in establishing a democratic order in Nepal. But it was, as we have seen in several earlier examples in the post-Rana period, the result of a "compromise" of a kind that contained some irreconcilable contradictions. These would prove more disruptive than many stakeholders foresaw at the time.

One such contradiction is between the statement in Article 3 that the sovereignty of Nepal is vested in the Nepali people and the emergency powers admitted to the king in Article 115. Previous constitutions from 1959 and 1962 had given the king the right to revoke the constitutions in their entirety and to assume all powers of government. Indeed, King Mahendra used this provision in 1962 to oust the elected government of B. P. Koirala. The article in the 1990 Constitution says that a proclamation must be ratified by the House of Representatives within three months. The constitution does not provide strong safeguards against the king's suspension of the elected parliament during an emergency situation. Commentators have held that the constitution's statement (Article 3) that "His Majesty is the symbol of the Nepalese nationality and the unity of the Nepalese people" reinterprets the role of the king from an autocrat to a constitutional monarch, especially since the formulation is connected to the provision that executive powers lie with the Prime Minister. This interpretation becomes highly problematic if we also consider the symbolic attributes of the king's person, as stated in Article 27(1) and the provision of emergency powers to him.

The much awaited and debated issues of defining the core attributes of the Nepali nation was "resolved" by the following contradictory statement in Article 4(1): Nepal is a multi-ethnic, multi-lingual, democratic, independent, indivisible, sovereign, Hindu, constitutional 
kingdom. ${ }^{48}$ The new constitution, in other words, reaffirmed Nepal as a Hindu state, founded on the institution of monarchy. This fundamental concept was also affirmed by Article $27(1)$, which stated that the king had to be a descendant of the Shah King that unified the nation, a maintainer of Aryan culture and a Hindu. The strongly articulated demands from ethnic groups and the regional party for recognition of their cultural rights were thus largely unmet. The constitution gives somewhat limited recognition to mother tongues as national languages (rashtriya bhasha) and to a right to run schools that can provide education in the mother tongue at the primary level. The regional Sadbhavana Party's demand for Hindi as a second state language was not met: only Nepali was given status as the state language.

Another defining feature of the Hindu king was his right as Supreme Commander-in-Chief of the Royal Nepalese Army. The constitution allowed the king to retain this right, and to appoint his Commander-inChief on the Prime Minister's recommendation. A National Security Council led by the Prime Minister will be in charge of all other military operations. These formulations, when seen in connection with the same constitution's concession of emergency powers to the king (which should be seen as a serious threat to the democratic elements of the constitution), would prove (see discussion below) to be significant after the insurgency started and the question of the Royal Nepalese Army's role in quelling the insurgency became a pressing issue.

Other strongly articulated human rights claims were also only partially accommodated: even if discrimination on the basis of sex was to be abolished, women were not in all respects accorded equal citizenship rights. $^{49}$

Considering the dramatic political events in 1990 , the first Jana Angolan might most appropriately be understood as a rebellion rather than a revolution. However violent and urban-supported it may have been, it did not fundamentally change the political order. At this point, certain historical parallels between the 1951 and 1990 uprisings can be discerned. Both the "palace rebellion" in 1951 and the 1990 "urban rebellion" lacked mass support in the predominantly rural population. Both occurred at conjunctures of significant change in the international order (the fall of the British Empire in South Asia; the fall of the Berlin
Wall and the subsequent democratisation). In 1951 as in 1990 , both the pro-democracy parties and the regime's loyal protagonists had ideological and social ties with likeminded political parties in neighbouring India, indicating a number of regional connections. In addition, the official Indian stance was of great importance, especially so in 1951. The Indian government and Indian political parties of secular and staunchly Hindu fundamentalist persuasion were active players during the 1990 events. New international actors (belonging to the donor community), however, had also gained considerable political leverage in Nepalese policies. In 1951, the democratic forces were out-manoeuvred in the political negotiations and presented with a political fait accompli. In 1990, the democratic forces gradually asserted a stronger agency through mass demonstrations. But this agency was considerably weakened by the ULF's internal ideological differences and by the tacit consensus on the indispensable role of the Hindu monarchy, which united the influential moderate Congress-led section of the ULF and the old regime.

The drafting of a new constitution in the volatile transition period nurtured great hopes that the constitution would indeed have agency as a "model" for the real restructuring of the political order. Such hopes were dashed. The "compromises" in the constitution would turn out to be irreconcilable, and a testimony to the shared upper-caste and Hindu elite orientation of the Congress and the old regime, and thus to the unresolved power contradictions between the authoritarian state and a rapidly diversifying civil society. The 1990 Constitution may thus more appropriately be analysed as a model of these politically contradictory and unresolved realities surrounding the negotiated "compromise".

\section{A Halted Democratic Transition and Institutionalisation of Human Rights}

The establishment of a multi-party system, the growth of a vital civil society, the ratification of a number of human rights conventions and the establishment of a National Human Rights Commission, all give the appearance of a democratic transition (between 1991-1995) with considerate efforts to institutionalise human rights. This subsection seeks to examine briefly how a contradictory development of political and civil rights and an uneven economic development unable to address basic 
social and economic rights of the great majority of the rural citizenry came to have destabilising consequences

Prior to the 1991 election, a plethora of new political parties sought registration, some of them lacking even an elementary political programme. The major political parties also underwent fissions, fusions and supporter shitts. Many former Panchayat leaders became members of the congress Party. a sign of the old political elite's opportunism. The Congress lader-ship weleomed this influx. as they hoped the panchas would give them an extended support base in the rural areas where their outreach was limited. The old patronage culture of exchanging allegiance for political offices flourished. Two of the leftist parties from the ULF merged and established Communist Party of Nepal Marxist-I eninist (CPN-UMl) and emerged as the Congress's main political rival. ${ }^{50}$ Among the other communist contenders was the Inited People's Front Nepal (the political wing of the (jnity (entre), which would soon turn from parliamentary politics and start playing a major role as an extraconstitutional force. In spite of the exodus to the Congress, two parties of earlier pomchas (politicians from the Panchayat period) ---. with dubious democratic credentials - stood for the clection. Both parties were headed by earlier l'rime Ministers from the pre-democratic period."

The 1991 election campaign in the rural areas was plagued by many parties inability to pursue a nation-wide campaign. Unlike the controversial royalist panchas and the united communist party (CPNUML), many lacked the basic party infrastructure in rural areas to engage in the campaign. Political repression by illegal and extra-political means was also fairly common.

Parts of the Rapti Zone (Rolpa, Rukum, Dang. Pyuthan and Salyan) of mid-western Nepal had long before the People's Movement (dating back to the $1950 \mathrm{~s}$ ) been an area of underground political agitation by the then underground communist movement. In fact, one of the national leaders, the veteran Mohan Bikram Singh, came from this area. The eastern part of Rolpa, formerly part of Pyuthan district, was already ruled by communists in 1957 (see de Sales, 2000). One of the Maoist splinter parties, CPN (Masal) called for a boycott of the 1991 elections. ${ }^{52}$ This call received widespread support, Pyuthan had the lowest voter turnout of all districts (see Thapa and Sijapati, 2003:66). The Samyutka Jana
Morcha (SJM) was the political wing of the CPN Unity Centre. ${ }^{5.3}$ The CPN Unity Centre had not joined the United I eft Front (ULF) alliance, but operated independently during the Jana Andolan. Many of the political cadres within the CPN (Unity Centre) had found the 1990 compromise near to unacceptable. Nevertheless, they decided to utilise the multi-party system to engage in open public advocacy in order to gain immediate parlianentary access, while retaining their longer term objective of a revolutionary overthrow of what they saw as a regressive regime. In the first General Election in May 1991 the Congress won seven of the II parliamentary seats held by the Rapti Zone constituentcies. SJM won three (two in Rolpa and one in Rukum) and the CPN-UML one. The support for the SIM is notable and relevant to our understanding as to why the Maoist insurgency later started in Rolpa and Rukum. Among the nominated Congress candidates, there were a sizeable number of leaders from the Panchayat era. Reacting against the placing of panchas high up on Congress lists, many voters chose to support SJM

The ensuing violent means of political competition between Congress and SJM cadres can only partly be explained by both parties' long history as underground movements, used to violent political methods. In addition to intact non-democratic institutional practices and party cultures untainted by even proto-democratic "rules of the game", two other factors were also of importance. One was the grossly unequal access of the Congress and the CPN-LML to the civil and military branches of the state apparatus. Another important factor to reckon with was the new availability of a public space in which political vendettas could be undertaken. ${ }^{5+}$ The general election was conducted relatively peacefully and reasonably fairly, indicating that elections were not a novelty in Nepal as such. About 65 percent of the electorate voted, a rather high rate compared with countries of similar levels of literacy, poverty and communication systems. But there was evidence of use of intimidation, vote rigging and vote purchase, suggesting that the turnout of genuine voters was somewhat lower than the official voter count. Two parties stood out as the winners. The Congress gained 54 percent of the seats ( 110 of 205 seats) and CPN-UML won 34 percent of the seats. The far leftist party SJM also did well in a number of constituencies and won nine seats. The two parties of the former panchas did very poorly and 
gained only four seats (HMG(N), 1991:179-181). The communist parties' entry into parliamentary politics was unprecedented.

Retrospective studies of the voting behaviour at a national level in the 1991 election show the core support areas and voter groups of the communists and the Congress in those critical years before the insurgency was launched. The communist parties did well in the Kathmandu valley and in central and eastern Nepal. Moreover, they did relatively well in the mountains and hills of the western and midwestern regions (such as the Rapti Zone). The Congress did quite well in the plains areas of the western, midwestern and far western regions. Congress's electorate drew heavy support from elderly voters in the traditional castes. The communists. on the other hand, had a younger electorate, coming from rural small-holder, urban working class and aspiring middle class backgrounds (See Borre, et. al., 1991:356-362; Kumar, 2001). The royalist party (RPP) drew mostly support from voters with an ethnic background.

From mid-1991, Nepal had a democratically elected, Congressheaded government and a promulgated constitution endorsed by most but not all the leftist political parties. In the following months, G. P. Koirala's government did not deliver on many of its promised initiatives. Also, the economic indicators were unimpressive, inter-party rivalry for spoils was on the increase and Indo-Nepali relations re-fuelled the political system and public. ${ }^{55}$ The parliamentary opposition again resorted to the streets, demanding Koirala's resignation. Even so, the Congress government stayed in power for another short period through the 1993 flood disaster and finally resigned in 1994 as a result of serious intra-party dissent. The parliament was dissolved. The mid-term election resulted in a hung parliament and the formation of a minority government headed by the party president of the CPN (UML), which had won the largest number of seats. SJM (Unity Centre-United People's Front Nepal), which had recently split, did not win any seats. The UMLled government was only in office for nine months, and was followed by a coalition government under Congress leadership, supported by the until then discredited party of the former panchas (Rastriya Prajatantra Party) and the Terai-based Nepal Sadbhavana Party.
This split in 1994 was indicative of the serious ideological disagreements within the SJM during the years 1990-1994. The party had found the 1990 compromise more or less unacceptable. Already in March 1992, SJM had presented the moderate-majority government with a list of demands. ${ }^{56}$ During the following weeks, they launched protest programmes which were met with police violence and the killings of demonstrators. Such excessive use of force could not but radicalise SJM supporters.

During the whole 1990-1994 period, the party engaged in intense ideological debates. These debates centred on the general applicability of Maoism as compared to Marxism and Leninism, in addition to the role of political struggle in relation to armed struggle and, in the case of armed struggle, the relative merits of rural and urban insurgencies. The ensuring dissent, also fuelled by personal rivalries, resulted in the purging of the minority fraction of the Central Committee. The minority fraction stood for the mid-term election as noted above. Also, the majority fraction wanted to partake in the election due to tactical reasons, but was not approved as a party by the Electoral Commission. Facing non-approval, they called for a boycott of the mid-term election, probably as a facesaving measure. This fraction went underground right away and started its preparations (both on Indian and Nepalese soil) for a new stage of struggle. These plans were forged in close dialogue with its sister parties under the auspices of the Revolutionary Internationalist Movement (RIM). Following the promulga-tion of the 1990 Constitution civil society in Nepal expanded very quickly and also diversified as a result of an enormous growth in the number of development-supportive and human rights-based international non-governmental organisations (INGOs) and non-governmental organisations (NGOs) in Nepal. This growth was non-evolutionary, and artificially rapid due to mainly two factors - both structurally related to the neo-liberal development paradigm: (1) a massive influx of development assistance increasingly geared toward supporting the NGO sector and, (2) massive establishment of national, regional and local NGOs by both former civil servants (who had lost their jobs due to structural adjustment measures) and by bureaucrats and politicians, who saw the creation of own NGO as both a viable strategy for economic diversification and for gaining a political voice in civil society. The massive growth coincided with the 
globalisation of new social movements increasingly addressing gender, religious and ethnic differences. Greater exposure to advocacy about gender justice and to formal employment gave increasing numbers of rural and urban Nepalese women a political consciousness of grievances and the importance of collective action. The globalisation of the new indigenous movement gave political legitimacy and direction to the new fluorescing of ethnically based-associations in Nepal. Considering the rate of growth and proliferation of civil society actors engaged in "the politics of difference", they could be seen as indicators of a considerable improvement in certain aspects of political and civil rights (the right to take part in the conduct of public affairs, the freedom of association and of expression, freedom of thought) in Nepal during those tumultuous years. But these indicators can only be meaningfully interpreted when they are put in a context of a much more thorough look at the accountability of the INGOS and NGOS. As the works by Bhattachan, Dahal and Bleic amongst others have shown, there were pressing questions both the $\mathrm{NGO}$ sector's dependency (and top down accountability) on northem donors; its urban, regional, caste and gender biases; weak accountability to community-based institutions (and the ultimate beneficiaries) and dependency on both the Nepalese state and on markets (see Bhattachan ct. al., 2001; Bleic et. al., nd.; Dahal, 2001). As is evident from both the above exposition and the subsection which follows, other aspects of political and civil rights (the freedom from arbitrary arrest and detention. equality before the courts, equal protection of the law, freedom from arbitrary and unlawful interference into privacy and home) were increasingly violated under the nascent multi-party democracy. This becomes particularly evident if we examine the deterioration of civil and political rights in the Rapti 7.one of midwestern Nepal, where the Maoist rebellion was initiated in 1996.

\section{Preparations for People's War}

Reports from human rights observers indicate that in Rolpa District alone, perhaps as many as 1,000 people were arrested between 1992 and 1996 under the Public Offences Act (See SAHRDEC, 1996). Allegedly, hundreds of SJM activists were harassed and were also facing false charges by NC and RPP party members. The 1992 local elections form the direct backdrop for these charges. The district administration. including the political authorities as well as the police and judiciary, did not handle these cases in a transparent and fair manner. In fact, evidence suggests the local elite party cadres acted in collusion with the police.

In 1994, SJM centrally decided to boycott the mid-term poll. CPNUML (which, based on the results, came to form a minority government) captured some of the earlier SJM voters. Also, NC obtained a favourable electoral result in the Rapti Zone. Reports of political and police violence in Rapti led the newly elected CPN-UML government to commission a report on the allegations. The report, which spoke of unlawful detention on false grounds and forced incrimination by police and local political leaders, was not widely published by the government, allegedly to not overstrain relations with the Nepali Congress (See SAHRDEC, 1996). Their local cadres were implicated in a number of the investigated incidents. As the Nepali Congress again came to power in 1995, the party's central and local leaders intensified their efforts in order to extend their voter support even further by undermining and taking over SJM's support base. Many SJM supporters chose to leave the party as it officially went underground. The party expelled those members who took part in the mid-term election. Many of those who did not partake went to live in India, where the Maoists had well-established collaboration with a number of militant leftist Maoist parties. Jointly, they started ideological and military preparations for an uprising on Nepal's soil. This uprising was seen as integral to a world revolution of the proletariat.

Observing closely both the developments at the central and local levels, the underground central leadership of the CPN (Unity Centre), the Prachanda Fraction, developed its final and consequential ideological considerations for the next stage of struggle. Party documents, interviews and the published writing of the Prachanda Fraction's chief ideologue Baburam Bhattarai provide us with few clues for judging whether the leadership devoted time to a last, specific political assessment of whether they should consider to make a final effort to create a broader popular movement in pursuit of a non-violent solution to the mounting cultural, political and economic contractions of the Nepalese society (see Bhattarai, 2003a and 2003b). 
As the formal decision for a protracted war was to be taken, in 1995 the Maoists' and their supporters experienced human rights violations by a new regime claiming to be democratic and accountable to its international human rights commitments. Precisely how these experiences affected the leadership's decision to opt for warfare is difficult to ascertain, but the experiences undoubtedly had a mobilising effect when they started to prepare ideologically and organizationally for the uprising in Rolpa and Rukum (two neighbouring districts). A forerunner of the uprising was the Sisne-Jaljala (the names of two mountain tops) campaign. This political campaign was started by the SJM in Rolpa and Rukum from May $1995 .^{57}$

In September 1995, a Congress-led coalition government succeeded the minority government led by CPN-UML. With a hawkish, law and order-oriented government, local politics in Rolpa and Rukum turned even more violent in the autumn of 1995 than in the previous years. Informal Sector Service Centre (INSEC), national human rights NGO, reported human rights violations in 1994 and 1995 by police forces in those areas of Rukum and Rolpa that were strongholds of the United People's Front (SJM). The same reports also contain accounts of SJM supporters' attacks on Congress workers (INSEC, 2002; 2003).

One major incident that led to further escalation of violence took place in Rolpa in October 1995 in connection with the launch of a cultural programme. A clash broke out between NC, RPP and SJM activists, leaving a sizeable number of supporters injured and arrested. ${ }^{58}$

The NC-RPP coalition government's response in NovemberDecember was a large-scale police operation called "Operation Romeo". 59 There are a number of reports documenting excessive use of violence and a large number of arrests (of both SJM members and of ordinary non-activists) on false or arbitrary grounds (See SAHRDEC, 1996). Most were arrested under the Public Offences Act. Reliable reports suggest that police made extensive use of the rape of women and girls as a collective punishment, in order to shame and humiliate. ${ }^{60}$ According to reports, party workers from the ruling party directed police searches of homes of UPF cadres in 11 villages in Rolpa (See SAHRDEC, 1996:12). Such acts discredited the forces of law and order, alienating local activists and ordinary villagers and fostering resistance among already radicalised political elements.

By late 1995, the fateful decision to engage in armed struggle was taken. The brutality of "Operation Romeo" thus suited the preparations of the central Maoist leadership of SJM for protracted warfare, to be launched in February 1996. On 4 February, the 40-point charter of demands was presented by the SJM Chairman Baburam Bhattarai to Prime Minister S. B. Deuba. The list contained demands for a new constitution drafted by a constituent assembly, abolition of the monarchy, abrogation of all unequal treaties with foreign governments, and several specific demands related to political, civil rights and economic rights (improvement of livelihoods) (see Thapa and Sinjapati, 2003:189-194). Before the deadline had expired, a number of government installations were attacked on 13 February. The political nature of these attacks is evident from the ways in which they were carried out. In the attacks on two police stations in Rukum and Rolpa, political slogans were shouted before and after the police were out-manoeuvred. No one was killed in these incidents. The attackers looted explosive materials and other valuables. The same day the plant of Pepsi Cola was attacked in Kathmandu and a liquor factory in Gorkha was blasted. These early attacks were ideological statements about the main targeted class enemies: the multinationals, local/national capitalists and the extended arm of the repressive government. ${ }^{61}$ The People's War, a military extraconstitutional means of realising the political aim of first establishing a "new democratic state" and eventually a communist state, was on. It would soon spread to other western and mid-western districts and further to the far west as well as some of the eastern regions.

Considering the 1991-1996 period as a whole, the early years of a multi-party system would have been challenging for even a highly competent government. With the old axis of palace together with the army and police being largely intact, added to an entrenched culture of patronage in the upper echelons of govemment and within the mainstream political parties, the most basic requirements for starting to establish democratic govemance based on answerability to human rights concerns were neglected. With simmering political discontent and a 
determined under-ground Maoist party with a regional support base, the situation was ripe for confrontational politics by using violent means.

\section{Violent Conflict Between 1996-2006}

As stressed in the introduction, this article does not pretend to explain in full the unprecedented escalation of the conflict between state forces and Maoist gucrillas and militias during the decade. Instead, I will briefly illuminate how the above analysis of constitutional wrangles as political struggles over the attempt to define a principle of sovereignty and the palace's ability to maintain and recreate extra-constitutional sources of authority is relevant for understanding (1) why the two efforts at negotiation apparently failed over the issue calling a constituent assembly, (2) why the issue of whether the king or the Security Council should control the army is so sensitive, (3) the repercussions of the royal massacre in June 2001 and how they interconnect with the current king's use of emergency powers.

When the nation was still in an early stage of grieving over the killings of the king. queen and their nearest relatives, the beleaguered Premier G. P. Koirala stepped down, due to being under investigation for the abuse of authority ${ }^{62}$ and a wrangle with the Royal Nepalese Army. Koirala gave way to one of his party opponents, S. B. Deuba, who had been arguing for some time that the Maoist insurgency was a conflict in need of a political solution. Deuba immediately declared a ceasefire (the announcement was reciprocated by the Maoists' military and political leaders) and started to prepare in earnest for negotiations. His political ambitions at that stage for solving the impeding crisis were related to his recent high-level contacts with the rebels, and also to his family connections to elite Ranas, who are influential within the Royal Nepalese Army. ${ }^{63}$ After the wrangle with the former Premier G. P. Koirala, the Royal Nepalese Army had an interest in showing a willingness to collaborate with the elected government. In spite of these enabling conditions, the negotiations failed in November 2001 after three rounds of talks.

The main reason for the breakdown was the Maoists' demands for a constituent assembly and a republican state. ${ }^{64}$ Nearly two years later, the government's dismissal of the Maoists' demand for a constituent assembly was again one major reason for the breakdown of talks after seven months of ceasefire. King Gyanendra's dismissal of the Deuba government and his assumption of executive powers in October 2002 formed the backdrop for the second ceasefire in late January 2003. The new royalist government, which was deemed illegal by the parliamentary parties, also contained ministers this time with a conducive mix of personal, caste/ethnic and royalist connections, mustering the social capital necessary to act as dialogue partners. ${ }^{6.5}$ The protracted negotiations again found themselves stranded ${ }^{\text {t6 }}$ in regard to the issue of a constituent assembly and the army's serious violation of the ceasefire the so-called Doramba incident. In response to the Maoists' demand for a constituent assembly, the govern-ment posed its version of constitutional monarchy, based on the principle of the sovereignty of the people Remarkably, this government party was appointed by the king, who had just violated this principle on grounds of extraordinary circumstances, as spelled out in Article 115 of the 1990 Constitution. The Maoist leadership, like so many of their communist predecessors, again failed to gain acceptance of their demand.

But much more important in the longer run, the Maoists managed to use the seven-month ceasefire to engage politically with the general public and mainstream political parties in a manner which lifted the demand for a constituent assembly to the national level. This widened sympathy for their basic demand is a step forward. So is, most definitely, an increased recogni-tion of its democratic rationale as a process leading to a new constitution that can be "a model for" reconstituting statesociety relations in Nepal. Even with this new openness to the demand for elections to a constituent assembly, however, there are justified concerns and fears about the road towards its realisation and about what kind of constitution would be the outcome. One such worry is how such elections could be conducted fairly in a far-flung country where, in many districts, government presence is confined to the district headquarters, and in a number of areas the Maoists are now the sole governmental and political actor. The party structures of all the parliamentary parties are mostly disrupted.

In January 2004, a spokesperson for the Maoists stated that they would be ready to accept a constitutional monarchy if the king were 
willing to relinquish his command of the army and accept that a sizeable number of military officials should be removed from their positions. ${ }^{67}$ This stance, if fully backed by the political and military leadership, is a significant signal of the Maoists' fundamental ideological and military concern with dismantl-ing the kingship-army axis as one founding pillar of the monarchical state. The demand for the axing of the top and middle level leadership of the army is also part of this dismantling strategy. It seeks to address the need to undermine the old axis between the top echelons of the military and the extra-constitutional centre, the palace. Thus, their recent move, if serious, could be understood as being related both to communist ideology in regard to how the conditions for transforming a semi-feudal state into a transitory democratic (bourgeois) state and later into a communist state can be established, and to the Nepalese communist movement's memory of the past 50 years of political struggle against an autocratic monarchical state. As the above discussion reveals, the Maoists' political predecessors have over and over again experienced the monarchy's firm backing from the army and police in remaining the centre of authority, whether this meant suspending constitutions or disregarding constitutional proto-democratic reforms.

As shown above, circumstantial convergences of international and national events both in 1950 and 1990 influenced the course of political events in Nepal. The 11 September attacks, which occurred during the second and third rounds of peace negotiations, came to alter Nepal's role with respect to the intemational security agenda. The world's only superpower and its allies placed the conflict in Nepal on their own mental and geographical map of Asian "terrorist hot spots", and therefore offered substantial military aid. The Nepalese government was not able to withstand the US and UK's mix of courtship and pressure, and opted for a military solution to the conflict. This was conveniently used by the new king, who declared a state of emergency on 26 November 2001 , using the aforemen-tioned Article 115 on emergency powers in the 1990 Constitution. The constitutional rights enshrined in the constitution were suspended, except the right to file habeas corpus. The Nepal Communist Party (Maoist) and its supporters were declared terrorists. ${ }^{68}$ Thus, the 11 September attacks were used by the executive monarch to alter some of the rules of the game and the relative strengths of the stakeholders fighting for control over the state. The Royal Nepalese Army was, for the third time in more than 150 years, mobilised against its own citizens. With the increasingly well-equipped and numerous army troops entering the battleficld, the number of deaths, casualties and human rights violations increased dramatically. Perhaps less immediately noticeable, but still very significantly, this deployment fundamentally altered the way the king (as Supreme Commander) was constructed as a sovereign. Since Nepal's imperial expansion was stopped by the Sagauli Treaty with the British in 1816, the king-army axis has built on the notion of protecting Nepal's stable national border. The employment of the Royal Nepalese Army against its own citizens undermines this border definition, and establishes a much more contentious basis for the notion of the sovereign warrior king. The deployment of the army was the culmination of years of dispute between previous elected governments, the army chiefs and the palace. The dispute reflects another defect in the 1990 Constitution. As a compromise, the king was conceded the position of Supreme Commander, but had to act on the advice of a National Defence Council (to be led by the Prime Minister). After 1990, the political system had neglected to assert their role in the Council. ${ }^{69}$

The murdered King Birendra's reluctance to mobilise the army against the Maoists guerrillas during the early years of the emergency is well-known, though this is not the full background for his tacit understanding with the Maoist leadership. The differences between the elected government and the palace over who was the commanding authority actually was given emphasis in 1999, due to the preparation for an internal security and development plan. This included the employment of the army in all seriously insurgency affected districts. As already discussed above, G. P. Koirala resigned partly over these wrangles. The army remained immobili-sed until after the Maoists overran a district headquarters in September 2000. Then it was mobilised for security duty in 16 districts and remained so until the declaration of emergency about a year later. This new, militarily engaged, highly visible king-army axis, oriented towards internal enemies, might in the short run consolidate the axis, as the army is tethered with new positions and advanced weapons. However, fighting in hilly terrain cannot be undertaken only by air strikes alone. As the losses of army personnel increase, resentment and hatred by the population caught between the combatants will also grow. In the face of such prospects of increasing de-legitimisation of the army, 
one can foresee the possibility of strategic alliances between elements in the army and other parties searching for a non-military solution.

Another key agent implicated in determining the role of monarchy in the short and longer term is the current King Gyanendra himself. The circumstances of this king's accession to the office are extremely contentious. As long as the official version of the bizarre events to the effect that the crown prince committed regicide because he was forbidden to marry his long-time girlfriend are not better substantiated, the great majority of Nepalese - with their acute historical memory of conspiratorial palace politics- will remain suspicious of the possible role of the current king and other surviving relatives in the massacre of his own brother, sister-in-law, their children and some other close relatives. This tarnished image of the Nepalese monarchy internationally is a mental burden on the intellectual middle class and elite, who are painfully aware that even the slightest hints of such serious allegations would result in full investigations in any state where basic judicial accountability mechanisms are in force. There might be indications of another parallel trend of a more distanced, reflexive attitude among the rural population in insurgency afflicted areas towards the monarchy. If these tendencies are reinforced in the coming years, the cultural hegemony of divine kingship shall indeed be under challenge in Nepal.

The king's political performance so far indicates that he might be ready to and capable of consolidating his power at the expense of any new deal between the state and civil society. He is, in other words, a worthy successor to the legacy of his authoritarian and unscrupulous predecessors, whose central place in the political history of Nepal was analysed in this article. The Kot Massacre in 1846 brought the Ranas to rule Nepal for a century. Then internal strife within the Rana family acted as a factor in the downfall of the Rana autocracy in 1950. Again intemal strife, whatever the actual circumstances were, struck in 2001 when the country was already facing a dramatic destabilisation. These notable, but less visible and discussed repercussions of the royal massacre on public support for the Hindu monarchy might very well accentuate the drift towards a republic in Nepal.
The years 2005- 2006: a Seeond People's Movement - ending in a Comprehensive Peace Accord

The last few years have seen political change of a structural kind in Nepal. The scenario has moved from a scemingly entrenched triangular conflict between the autocratic and power-sceking royal regime, a fragile seven party alliance and a still assertive Maoist movement, to a basically bi-polar conflict that evolved into a second people's movement, which finally pressured a recalcitrant ruling monarch to reinstate the dissoived parlianent. The reinstated House of Representatives enacted a number of historical decisions. The state was declared as secular and constitutional control and control over the army was transferred from the kingship to the parliament. The parliament also accelerated the stale peace talks with the CPN (Maoist), by opening up for real negotiations over the most disputed issues, including the future role of the monarchy, the composition of the interim government, modalities and functions of the Constituent Assembly and of the disarma-ment, demobilisation and reintegration process

Let me first describe in some details the trajectory of this rapidmoving political transformation, which many would say, is unprecedented. The Communist Party of Nepal (Maoist) support for the agitation of the seven-party alliance (SPA) could not but in the longer run weaken the King's bargaining position. The agreement between the new partners was mainly limited to the issues of the royal takcover and constituent assembly, as the CPN (Maoist) opposed the SPA's demand for revival of the House of Representatives. The alliance's "roadmap" for peace was no doubt inade-quate, due to its heavy reliance on the political and constitutional events of the 1990-movement. The roadmap's inadequacy also reflected the ongoing intra- and inter-party conflicts and the increasing gap between senior leaders still supportive of the constitutional monarchy, and second and third-generation leaders who were increasingly supportive for at least a real debate about a republic. One might say that the alliance's roadmap was hopelessly outdated, as it promised a retum to a parliament and a leadership that in fact had contributed to the conflict escalation in the first place.

The 12-point pact from November 2005, between SPA and the CPN (Maoist) to oppose the royal takeover, should nevertheless provide one 
important precondition for the popular movement that unfolded unprecedented over 19 days (April 6-24). This amorphous movement" expanded its support-base day by day and came to include all sections of the citizenry; also district towns became the hubs of popular demonstrations whose force and message of the importance of human rights, peace and democracy had a self-reinforcing effect. The attention to the excessive use of force against demonstrators in intemational and domestic media, protests from the diplomatic community and international human rights groups and Nepalese Diasporas, served to strip the regine for whatever remained of its legitimacy and facilitated the final outcome. The final days of the movement became a demonstration of a diversity of popular expressions of women, youths, children, elders who had never taken to the streets before and the sections of the citizenry who were quite experienced street fighters. The masscharacter of this movement and its democratic and peace-promoting aspirational values, make it reasonable to argue that the Second People's Movement of April 2006 was different from the rebellions of 1950, 1979 and 1990, whose character I have analysed earlier in this paper.

On April 24, the hard pressured and domestically and internationally discredited King Gyanendra announced the restoration of the House of Representatives that he had dissolved in May 2002. Shortly thereafter, on May 18, the House of Representatives declared itself the sovereign body in the country, and dissolved the Royal Privy Council, reduced the power and the privileges of the Kingship (such as the right to decide heirs for the throne) and the Nepalese state was declared as secular.

This early accelerated phase between April and June 2006 was followed by a much more contracted and unpredictable phase of tough negotiations over the most contested issues: the status of monarchy, the interim constitution, composition of the govemment, the modalities of the constituent assembly and arms management. The tireless efforts of a number of principal negotiators, pressure from the continued people's movement and the intentional community, eventually resulted in the 10 point Comprehensive Peace Accord (CPA) that was signed after the SPA-Maoist summit meeting by Prime Minister Girija Prasad Koirala and Chairman of the CPN (Maoist) Puspa Kamal Dahal (Prashanda) on November 21, 2006.
The CPA"s preamble is an expression of the agreement as a compromise between a revolutionary movement, which indirectly state it ends the early 11 year long "people's war" and the mainstream political parties." The CPA contains objectives and directive principles for restructuring of the Nepalese state, goals for reforms of state-bearing institutions, decisions to form (interim) institutions and bodies like the constituent assembly. As has been remarked earlier in this paper, constituent assembly has been a longstanding demand, dating back to the early phase of communist party politics in Nepal. The Peace Accord also spells out the conditions for a pemmanent ceasefire, demobilization, disarmament, reintegration and resettlement.

While these political developments have been characterised as unprecedented, they are explainable within the framework of analysis of this paper. The simmering and action-inducing collective consciousness as citizens among the rural and urban populace, that triggered the (largely peaceful) mass-character of Second People's Movement, was based on a convergence between certain distinct political movements and related consequential events from 2001 and onward. The Maoist movement's decade-long ideological awareness raising about the nature of the Nepalese state gradually affected large sections of the society, and the civil society's (and some media houses) steady-fast espousal of liberal democratic values of social justice and participation (backed by the international community, though not always united) came to reinforce one another - opening up a genuine public questioning of the old hierarchical order centred on divine kingship. The circumstances around the royal massacre and the questions of trust surrounding the successor King and the Crown Prince, and the decision to deploy the Royal Nepalese Army against the country's own citizens, served to intensify the de-legitimisation of the century-old state-bearing model of a sovereign king, protecting his people against foreign invaders.

\section{CONCLUSION}

The Nepalese Hindu state was formed by the combination of brute force and more benign co-optive and assimilationist political and social strategies. Consent was built on cultural models of divine kingship, of the bond between rulers and subjects and of a caste-based social order. These 
models gained a hegemonic status through state and state-sponsored rituals which displayed the king's power in the representative public domain, through the bureaucratic court-centred culture, and a civil code as well as land tenure and taxation system that the Rana rulers appropriated and consolidated. In order to balance Nepal's sovereignty with continued domestic control of the state apparatus, the Ranas accepted a certain level of semi-dependency under the British in exchange for their non-intervention and acceptance of an isolationist policy. During the rule of the Shahs and Ranas, the Nepalese state developed a historical trajectory which had certain unique features. This apart. the Nepalese institution of kingship shared certain basic structural similarities with Indian princely states, whose actual power had been drastically curbed by the British, who remained tolerant of the pompous state rituals. The Rana rulers" isolationist policy, in a state based on rule by command and an honour code that made political dissent a religiously sanctioned sin, limited even the elite's exposure to Westem political ideas of democratic governance and a body politic of elected rulers and citizens.

The carliest exposure to any such ideas occurred in the 1920 s and 1930s. This exposure grew stronger in the 1940s as a direct result of the nationalist independence struggle, which eventually led to independence and a completely new political regional scenario. The events prior to and during the 1951 revolt, known somewhat misleadingly as ending autocratic Rana rule, were rather intimately orchestrated by the newly independent democratic Indian government, whose security interests had primacy over the more uncertain prospects for genuine democratisation in Nepal. The course of development in Nepal during the following decades was predicated hy the Indian economy's increasing dominance and successive Indian governments' somewhat weary tolerance of the preservation of autocratic rule - including the regime's successful containment of the seeds of democratisation sown by B. P. Koirala's brief period in government. The geopolitical location of the mountain kingdom between two very large countries, communist China and democratic India, set the terms for the pragmatic foreign policies of Nepal's rulers, and provided them with sufficient political space to consolidate their control over the state apparatus, together with a nationbuilding project that became more contentious than during the earlier Shah and Rana periods.
After the 1951 palace rebellion, the ruling monarch quite successfully managed to accommodate the expectations of the post-war international community, newly independent India and the traditional elite by embarking on a modest modernisation of the state. The rapidly growing influx of foreign technical assistance and financial support facilitated and accelerated this process of restructuring, which successive ruling monarchs followed up. By continuing to offer the traditional elite privileged access to leading positions in the expanding civil and military state apparatus while also acconmodating to some degree the emerging elites and aspiring middle class (groups whose very existence was the result of new in-country educational opportunities), the monarchs managed to consolidate their power. The aid-dependent expansion allowed the flowering of a patronage-based and Ilinduized bureaucratic culture, which, in the short term, strengthened both centralisation and the monarchy. The concentration of authority in the hands of officials at the palace created a classical mismatch hetween authority and responsibility, distorting clementary principles of accountability and favouring personalised ad hoc decisions, informal communication channels and disregard for basic principles of competence and impartibility. Pinpointing how a new, complex and potentially destabilising form of economic semi-dependency developed after 1950, this article has analysed Nepal's political and administrative development between 1950 and the late 1990s. A new critical form of reliance on Western donors developed, in addition, an increasing economic dependence on India and a less solid reliance on China.

While the regime was fairly successful for the time being in bargaining expanded cconomic and educational opportunities against acceptance of a limited kind of participation in "advisory" political assemblies during the Panchayat period, the highly discriminatory nature (towards service castes, ethnic groups and women) of this process of integration, which was not only not effectively redressed but accentuated by the development programmes of the $1970 \mathrm{~s}$ and $1980 \mathrm{~s}$, created a simmering process of political conscientiousness with respect to relative deprivation, injustice and state responsibility. The communist parties which operated as much on Indian as on Nepali soil in the $1980 \mathrm{~s}$ in spite of their internal ideological struggles consolidated their position as an 
alternative political voice to the Western liberal one, which was espoused by the patrons of aid.

The 1990 movement was in certain respects triggered by regional and international political events. And the form of the movement in certain respects shows national political agents' active use of models for political action that were disseminated by the international media. The exposition has illuminated how frail the alliance was, fraught by memories not only of past decades' ideological differences, but of personality clasbes and opportunistic power politics. The political agency of the movement was not only stifled by this frail foundation for joint action. The movement was also stifled by the partially co-opted position of certain key political actors (most importantly the Congress's) within the old regime. This co-optation was helped by the Congress politicians' adherence to the hegemonic notion of a Hindu monarehical state. The old political elite were also fractured. Hardliner panchas stood against panchas with dentocratic leanings. The negotiated compromise and contradictory constitution were largely results of these structural conditions' containing and crippling effects on the 1990 movement. The uneven alliance between the old palace-centred regime and the moderate and rightist parties more appropriately characterised as patronage-based networks created an array of effects bound together in mutually reinforcing ways that virtually blocked any institutionalisation of accountability mechanisms. Since a number of the connections and their cause-effect-cause chain-like nature are still inadequately researched, the question of the relative responsibility of the main leftist forces - the United Front, Communist Party of Nepal (Maoist) and CPN-UML - and of the non-partisan democratic middle-class for neglecting to join political forces to obtain a basically political solution during the 19911995 period remains a sensitive and unresolved issue in the face of increasing death tolls and the destruction of Nepal's infrastructure.

The analysis has shown how the last 50 years of political contention and partly failed efforts to restructure the monarchical state in Nepal have to be in no small measure explained as the result of contradictory multi-scaled regional (Nepalese-Indian) interdependences. These were found at the levels of govermments (security policies versus a boarder panacea of political and economic priorities), the parliamentarian party systems (the orthodox royalist parties versus the social democratic and some communist parties), civil socicties (also comprising underground revolutionary communist parties), and lastly at the level of a shared Gangetic Hindu culture- affording religious and political legitimacy to the Hindu monarchy. The CPN (Maoist) international connections, also expressed through proclaiming the "People's War" as the vanguard for a world revolution, have recently created new global-regional and local interdependencies.

Political institutions in Nepal after the introduction of multi-party democracy were not restructured either to respond to or fully to contain the new pluralist, centrifugal forces fuelled by structural adjustment and a rapidly expanding civil society. Like a "pressure cooker without a safety valve", an intolerable pressure built up that resulted in the declaration of war by a Maoist party bent on dismantling the monarchical state and perusing a phased strategy for attacking the key functions of this state and stripping it of what remained of its legitimacy.

The Second People's Movement, and the reinstated House of Representative's historical constitutional decisions, including to declare Nepal as a secular state and to open up for a negotiated settlement, lead after a period of tough negotiations to the Comprehensive Peace Accord, signed in late 2006. With a restored multi-party democracy, a peace accord whose implementation requires continued commitments from several stakeholders, a government authority with weak accountability, gender, caste and ethnic-based social exclusion, a war-tom economy and a radicalised citizenry, the consolidation of peace in Nepal depends on a difficult social transformation in the years to come.

\section{ENDNOTES}

1. This article is a revised version of "The historical path to violent destabilization in Nepal: elements of an explanatory transework" in Human Rights in Development: Empowerment. Participation. Accountability and Non-Discrimination: Operationalising a Human Rights-Based Approach to Development (Volume 8). edited by Martin Scheinin and Markku Suksi, published by Martinus Nijhoff Publishers (2005). This article benefited from comments from Dev Raj Daha!, Ram Chhetri, Krishna B.Bhattachan, Mukta I ama, Hugo Stokke and two anonymous reviewers. Acknowledgement is extended to Koninklijke Brill N.V (which incorporates the imprints of 
Martin Nijhof Publishers. 13rill. Hotei Puhlishing and IDC Publishers) for granting me permission to publish this revised article.

2. The clashes between the Peoples I.iberation Army and the militia on the one side and the Armed Police Foree and Royal Nepalese Army on the wher had. between February 1996 and late January 2004 , killed 8.826 people (many of them civilians) as well as injuring several thousands. See INSEC (Informal Sector Service (entre). at: http://www insec.org.np/killings / dala 14 February 2004. As a Peace Accord is signed. one can establish the exact death toll, which is expected somew here between 15.500 and 16.000 .

3. For an in-depth review of anthropological and historical colonial and postcolonial theories of the divine state in South $A$ siat. see Ronild Inden. Imagining India (Oxtord: Basil Blackwell. 1990).

4. Accountability refers to mechanisms by which the population/citizenry can make the authorities answerable for addressing -... or failing to address concems grounded in human rights. See Bleie et al. (2002).

5. The four basic categories of mechanism are judicial, quasi-judicial. administralive and political.

6. The unification in no way ended conflicts within and between fractions of the political elite, which was predominantly composed of high castes, but also of tormer trihal chiefly families who had heen offered civil or military positions and had managed to elevate their status as Ksatriyas.

7. See Prayag Raj Shama (1997). There have been some discussions ahout why the notion was incorrectly transposed as four jats and 36 varnas in the original text.

8. Since this Rana patrilineage was not of high-ranking Chhetri descent. it became eritically dependent on Brahmin priests for manufacturing gencalogies and assistance for other rank-seeking strategies.

9. See Uprety, Political Awakening in Nepal (1992). The sanad declares the king's indirect confession of previous acts of tyranny and his surrender under the extended authority of the Premier.

10. This network was centred on the Dasain festival and patronage of earlier tribal deities. For in-depth documentation and analysis, see fone Bleie and I ok Bhattarai, (2002) and Joanna Pfaff-Czarnecka. (1993).

11. For a most insighttul and claborate exposition, see Andras Hufer (1979).

12. According to Uprety (1992), there were only seven Europeans in Kathmandu in the first quarter of the twenticth century: the British envoy, his nicce, an Fnglish electrical cngineer with his family and a nurse employed at the court. Also, residents in the capital needed passports to leave Kathmandu. Likewise. residents from the plains needed passports to enter through the gates of Kathmandu.

13. The Gurkhas represent the first-ever integration of any Nepalese professional group into the globalised economy.

14. Prachanda Gorkha was among the earliest militant groups aimed at overthrowing the Rana oligarchy and establishing a constitutional government in Nepal. See Uprety (1992:59-63). The term Prachanda (meaning a fiery revolter) is currently used by one of the Maoist leaderships as a pseudonym and name for their revolutionary policy (The Prachanda Path). Though brutally eradicated. the Prachanda Gorkha gave inspiration to the Praja Parisad. the first organised party in Nepal. See Uprety (1992:6783).

15. These included the country s first-ever constitution in 1948. which granted some civil rights but reaffirmed the hereditary rights of the Ranas.

16. A constitutional convention is a special gathering pursuant to constitutional or extra-constitutional authority, 10 deliberate on the revision or replacement of an existing constitution, or to write a new constitution. A well-known case in Furopean history is the 1792 French assembly, where the republic was proclaimed, the king was given the death penalty (and executed) and the assembly committed itself to rule France for a short period. See Robert $\mathrm{L}$. Maddex (1996:70).

17. Mukti Sena was launched with arms from the Burmese government at the same time as the royal family fled from Kathmandu. See Brown (1996:18).

18. Rose also argucs (1971:191-192) that the refugec King Tribhuvan, under guidance from the Indian authorities, did not come out with a public statement in favour of the Nepali Congress and its Mukti Sena. The Indian authorities also placed restrictions on Mukti Sena's movements on Indian 1erritory. According to Pamanand (1982:41). perhaps as many as 3.000 Indians joined the Mukti Sena despite the official Indian position.

19. The land tenure category birta was abolished. An expanded and partly new bureaucratic apparatus with ecrtain organisational resemblances to modern Western bureaucracy was established.

20. Secretariat positions were granted to loyal royalists and alternative organisations like Royal Commissions were formed to bypass the Council of Ministers. Sec. e.g., Joshi and Rose, supra (note 29), p. 227, and Brown, supra (note 23), pp. 30-31. 
21. During the Rana rule, the number of civil servants increased from around 2,700 (in 1849) to 7,000 in 1951. In 1963/64, the numbers had more than quadrupled to 29,000 . A decade later they were 49,000 , and two decades later (1983/84), they had risen to 79,000 (for details see Pandey, 1989:315329).

22. The Koirala government managed to negotiate a new Treaty for Trade and Transit that was more favourable than the massively imbalanced 1950 Treaty.

23. Village assemblies were elected. They elected the district assemblies, which in their turn elected the zonal representatives, who elected a certain portion of the members of the National Assembly (Rashtriya Panchyat). The absolute monarch maintained the right to appoint 20 per cent of the members. Four memhers were elected by the Graduates' Constituency.

24. The National Assembly (Rashtriya Panchyat) was, in practice, not the sovereign legislative body. The Central Secretariat, which had no constitutional basis. was the de facto supreme decision-making hody, accountable only to the monarch. See Brown. 1996:44.

25. According to (Baral, 1977:110-145), some of the class organisations were also channels for regime critique.

26. The samc ritual could he observed as recently as in $200 \mathrm{I}$ and 2002 (also shown on Nepali Television), when the new ministers thanked King Gyanendra for appointing them.

27. On a daily basis, the official newspapers contained many reports about royal attendances and initiations of anything from new road links to trade fairs.

28. In order to manipulate the picture of relative predominance of different languages, the regional languages in the Terai were classified in the 1971 Census as separate languages and not as Hindi dialects, so as to render the number of Hindi speakers low. See Burghart, (1994:4).

29. The land reform was implemented and the caste system formally abolished. These measures created goodwill among educated intellectuals and the foreign missions. However, these enacted reforms were not backed hy any comprehensive sets of measures, which were necessary to redistribute land effectively and undermine the entrenched caste hierarchy (Cf. Joshi and Rose, 1966:475).

30. According to another study by Lok Raj Baral (1983:165-166), as many as 60 pereent of the then members of the National Assembly were made up of defectors from the political parties.
31. Whilc according to the line management structure, the civil service is answerable to the Council of Ministers, there was a contravening constitutional provision that made the Council only responsible for day-today management, lcaving the king and his secretariat responsibic for all politicat decisions (See Pandey, 1989:319).

32. Emhezzlement was considered theft under Rana rules and punishable by law.

33. The Service Commission under the first Koirala government prohibited civil scrvants from seeking support from the Palace Secretariat. but the Commission's reforms and the later Civil Service $\Lambda \mathrm{ct}$ have been largely ignored.

34. There were several interacting factors at play of which the aforementioned failed and reform was but one. Also, the Nationalisation of Forests Act led to decreased community access to vital resources: the population in the hills increased rapidly while the absolute limit for expansion into new arable agricuitural land in this ecological zone had been reached.

35. A Royal Nepal plane was hijacked by Nepal Congress activists, the residence of the Central Secretariat was bumed down and a grenade was thrown at the newly enthroned king during a visit to the border town of Biratnagar.

36. See Thapa and Sijapati (2003:43-50), for a more schematic genealogical exposition of fisions and fissions within the communist movement between 1949 and 2002

37. These included the establishment of the Social Services National Coordination Council responsible for supervising and approving community development (including donor-sponsored ones) and the National Sports Council, a kind of semi-military unit.

38. The fall of the communist regime in East Germany was of course noted, but perhaps even more so some of the subsequent falls of dietatorships. The fall of the Romanian President Ceausescu, who had come on an official state visit to Nepal in 1987, made a special impression (see Brown, 1996:114).

39. Two major communist parties joined the alliance: the NCP (MarxistLeninist) and NCP (Marxist), as well as the Varma, Manandhar, Amatya and Fourth Congress fractions, added by the Workers and Peasants Party.

40. The human rights violations included indiscriminate firing, false allegations without securing detainees' rights to legal assistance and trial, mass arrests of demonstrators, detention and imprisonment under torture, unsanitary 
conditions. without trial and censorship (see Amnesty International. 1990a and $1990 \mathrm{~b}$ ). The police violated hasic moral and religious codes by not returning dead bodies for funcral rites.

41. Information about the royal family's economic interests was circulated and also comments that amounted to a critigute of the traditional notion of the state's treasure ats the sovereign's own purse.

42. See Brown's (1996:25-127) account based on interviews with the mos prominent political leaders.

43. Brown. (1996:137-139) stresses that the Indians" backstage polities is not fully known. But it seems clear that the Indians were actively engaged in forcing concessions from the king and in trying to promote a draft treaty which would have limited Nepal's sovereignty in certain respects (personal communication. Dev Raj Dahal).

44. Some leading Indian politicians gave full support to the movenent. Also. Indian activists gave assistance along the border. See Brown. (1996:137).

45. Krishna P. Bhattarai (President of the Congress Party) was appointed Prime Minister. The Council of Ministers was composed of four ministers from the Congress, three from the ULF, wo nominees of the king and two independents.

46. One commission investigated disappearanees during the Panchayat period and the other (the Malik Commission) alleged violations during the Jana Andolan (between 18 Fehruary and 13 April). None of the reports were published. The Malik Commission made suggestions for action against the ultimately responsible officials within the police, in the Council of Ministers and in the administration. The Attorney General did not take any legal action, relying on a scries of extremely unconvincing arguments.

47. For a detailed account of the whole drafting process, see Michael Hutt (1994), One of the (in)famous incidents during the drafting was the version released hy the palace on 21 November. The draft, which gave the kingship very extensive powers, was claimed to have been written in consultation with the Prime Minister. For details see also Brown (1996), and Raeper and Hoftun (1992).

48. See the official translated version of the constitution: $\operatorname{HMG(N)}$ (His Majesty"s Government of Nepal), The Constitution of the Kingdom of Nepal $20+7(1090)$.

49. Article 9 gives only children of male citizens the right to be acknowledged as Nepalese by descent.
50. The Nepal Communist Party (Marxist) and the Nepal Communist Party (Marxist-Leninist) merged into the Communist Party of Nepal (tinitied Marsist-L.eninist).

51. The National Democratic Party (Rashtriya Prajatantra Party) was headed by Surya Bahadur Thapa. Thapa held the office of I'rime Minister during the dramatic days of April 1990 and thus was discredited in the eyes of the political left. The other pary was headed by I okendra Bahadur Chand. Both would return as Premiers after the people's war had started.

52. (PN (Masal) was one of the splinter parties of the party atso having the name CPN (Masai), which was formed by Mohan Bikram Singh in 1983. In 1984. this party was one of the founding members of the Revolutionary Internationalist Movement (RIM) (see Thapa and Sijapati. 2003:27).

53. The (l'N (inity Centre consisted of CPN (Mashal). (PN (4th (ongress) and a splinter group of (PN (Masal). which had got registered by the Electoral Commission in early 1991.

54. See SAHRDLC's (1996:8-9). which argues that many instance of personal animosities supported under the Panchayat system were translated into political conflicts in the new public space created by the multi-party system.

55. The Tanakpur Agreement between India and Vepal became a matter of serious political contention, as the constitution was ambiguous on the terms for ratilication. The Supreme Court ruled in Decenber 1992 that the treaty should have been ratified by the parliament.

56. The full list is published in Thapa and Sijapati, (2003).

57. See the reference in SAHRDEC (1996). 10 an interview in 1996 with the crstwhile Deputy Superintendent (DSIP) of Police in Rolpa. The IDSIP saw the Sisne-Jaljala Movement as the real start of the People's War.

58. Or the 24 people arrested, seven of them were charged under the Public Offences Act of 1970 and 13 for altempted murder. SAIJRDC (1996).

59. Aceording to Thapa and Sijapati (2003:71). the operation was headed by a Congress Home Minister known to be a ruthless politician. He was already sued in a criminal case. accused of heing implicated in a fatal shooting incident which killed UML activists during the 1994 mid-term election. After he became Home Minister, it seems he managed to stop the case from being pursued in the court system.

60. Baburam Bhattarai's view of what happened during Operation Romeo was referred to in The Independent, 13-19 December 1995. 
61. See the ML Party's own article on these incidents in New Worker. No. 2 (1996).

62. G. P. Koirala was under formal investigation by the Commission for the Investigation of Abuse of Authority (sec Thapa and Sijapati. 2003:115).

63. K. P. Bhattarai's short-lived government in 1999 appointed Deuba as the leader of a high-level committee to suggest solutions to the Maoist problem. After promising initial contacts. the bitter intra-party dissent over the initiative resulted in Bhattaraîs fall, and his critic G. P. Koirala, who advocated a law and order approach to the Maoists. again became Prime Minister.

64. Fvidence about how the Maoists used the ceasefire to reorganise politically and militarily suggests that they had little faith in the negotiations. Immediatcly after the breakdown. the Maoists proclaimed the establishment of their parallel National People's Government and a number of large-scale offensives were launched in various parts of the country. Sudhir Sharma, Tbe Lthnic Dimension of the Maoist Insurgency (draft), (Kathmandu, 2002).

65. Minister Naryan Singh Pun. strongly royalist Magar and successful businessman. is a good example of such a pro-regime actor.

66. Both parties showed no commitment to follow the agreed Code of Conduct and preparations were poor. Both parties' official statements were inconsistent. Both sides were influenced by hardliners who pushed for military solutions. There was no proactive support from the parliamentary partics, which were nol a formal party to the negotiations and whose main agenda was the reinstatement of the parliament.

67. Sce http:/www.kantipur.online.com/php/kolnews.phs\&nid. 22 January 2004.

68. The basis was a Terrorist and Destructive Activities Control and Punishment Ordinance, which was followed in 2002 by the Terrorist and Disruptive Activities Act (IADA).

69. Former Chief Justice Bishwanath Upadhyaya, who drafted the constitution in 1990 and also the Civil Code in 1964 under King Mahendras autocratic regime, is unusually blunt about this omission in a recent interview in The Kathmandu Post (available at: http://www.nepalnews.com/Kathmandupost, 12 January 2004). He says: "Even in the case of the army, the constitution formed a Defence Council with the majority of parliamentarians to operate this body. But the political parties never asserted their role and let the king operate such a sensitive organ."
70. For a valid viewpoint questioning the role of civil society in the sccond people's movement see C.D. Bhatta's article in The Rising Nepal on 27 July 2006: Role of Civil Society in Conflict Resolution, also available at http://nepaldemocracy.org/conflict.

71. The CPA states in its preamble "Pledging for progressive restructuring of the state by resolving prevailing problems related to class. ethnicity. regional and gender differences." The preamble continues by stating: "Reiterating commitments to competitive multiparty democratic system, civil liberties. fundamental rights, human rights, complete press freedom. rule of law and other norms and values of the democratic system". Available at http://www.nepalnews.com/archive/2006/nov/nov08/Full_text_summit_mee ting.php

\section{REFERENCES}

Amnesty International, 1990a. Amnesty Nepal: A Summary of Human Rights Concerns London: Amnesty International.

Amnesty International, 1990b. Amnesty Nepal: A Memorandum to the Government London: Amnesty International.

Baral, Lok Raj. 1983. Nepal's Politics of Referendum: A Study of Groups and Personalities and Trends (New Delhi: Vikas Publishing House Pvt L.td).

Baral, Lok Raj. 1977. Oppositional Politics in Nepal (New Delhi: Abhinav Publications).

Bhattachan, Krishna et al. (eds.). 2001. NGO, Civil Society and Government in Nepal (Kathmandu: Central Department of Sociology and Anthropology and Friedrich-Ebert-Stiftung).

Bhattarai, Baburam 2003b."The Political Economy of People's War", in Arjun Karki and David Seddon (eds.). The Pcople's War in Nepal: Left Perspectives (Delhi: Adroit Publishers), pp. 117-164.

Bhattarai, Baburam. 2003a. The Nature of Underdevelopment and Regional Structure of Nepal: A Marxist Analysis (Delhi: Adriot Publishers).

Bleie, Tone and Bhattarai, Lok. "Sovereignty and Honours as a Redistributive Process", Furopean Bulletin for Himalayan Research, Vol. 23, No. 1 (2002), pp. 26-55.

Bleie, Tone et al. 2002. A Rights-based Approach to (Norwegian) Development Assistance. Commissioned Report to the Royal Norwegian Ministry for Foreign Affairs (Bergen: Chr. Michclsen Institute).

Bleie, Tone, Bhattachan, Krishna and Bhattarai, Lok. From Himmelbjerget til Himalaya: MS in Nepal, available at: http//:www.danida.dk.evaluationsdisc. 
Borre, O., Panday, S. R. and Tiwari, R. 1991. "The Nepalese Election of 1991", Electoral Studies, Vol. 19, No. 4, pp. 356-362.

Brown, T. Louise. 1996. The Challenge to Democracy in Nepal (London: Routledge).

Burghart, Richard 1994. "The Political Culture of Panchayat Democracy", in Michael Hutt (ed.), Nepal in the Nineties: Versions of the Past, Visions of the Future (Delhi: Oxford University Press), pp. 1-14.

Dahal, Dev Raj. 2001. Civil Society in Nepal: Opening the Ground for Questions (Kathmandu: Centre for Development and Governance).

de Sales, Anne 2000. "The Kam Magar Country, Nepal: Between Ethnic Claims and Maoism", European Bulletin of Himalayan Research, No. 19, pp. 4171.

Hayes, Louis D. 1975. "The Monarchy and Modernisation in Nepal", Asian Survey, Vol. 15, No. 9, pp. 616-628.

HMG(N) (His Majesty's Government of Nepal), 1991. House of Representative Members' Election - 2048: Final Results (Kathmandu: Election Commission).

HMG(N) (His Majesty's Government of Nepal), 1990. The Constitution of the Kingdom of Nepal 2047 (1990) (Kathmandu: Ministry of Law and Justice and Parliamentary Affairs).

Høfer, Andras. 1979. The Caste Hierarchy and the State in Nepal: A Study of the Muluki Ain of 1954 (Innsbruck: Universitätsverlag Wagener).

http://www.kantipur.online.com/php/kolnews.phs\&nid, 22 January 2004.

http://www.nepalnews.com/archive/2006/nov/nov08/Full_text_summit_meeting. php

Hutt, Michael 1994. "The Drafting of the 1990 Constitution", in Michael Hutt (ed.), Nepal in the Nineties (Delhi: Oxford University Press), pp. 28-48.

Inden, Ronald. 1990. Imagining India (Oxford: Basil Blackwell).

INSEC (Informal Sector Service Centre) at: http://www.insec.org.np/killings / data, 14 February 2004.

INSEC (Informal Sector Service Centre).Human Rights Yearbook 2002 and 2003 (Kathmandu: Informal Sector Service Centre).

Joshi, B. L. and Rose, Leo E. 1966. Democratic Innovations in Nepal: A Case Study of Political Acculturation (Berkeley: University of California Press).

Kumar, Dhruba. 2001. Social Structure and Voting Behaviour in Nepal (unpublished report), (Kathmandu: Nepal Centre for Contemporary Studies.

Maddex, Robert L. 1996. The Illustrated Dictionary of Constitutional Concepts (London: Routledge)
Pandey, D. R. 1989. “Administrative Development in a Semi-Dependency: The Experience of Nepal", Public Administration and Development, Vol. 9, No, 3, pp. 315-329.

Parmanand, 1982. Nepali Congress Since its Inception: A Critical Assessment (New Delhi: B. R. Publishing).

Pfaff-Czarnecka, Joanna. 1993. "The Nepalese Durga Puja Festival or Displaying Military Supremacy on Ritual Occasions", in Charles Ramble and Martin Brauen (eds.), Anthropology of Tibet and the Himalayas (Zurich: Ethnological Museum), pp. 270-286.

Raeper, William and Hoftun, Martin. 1992. Spring Awakening: An Account of the 1990 Revolution in Nepal (New Delhi: Viking).

Riedinger, Jeffrey. 1989. "Prospects of Land Reform in Nepal", South Asia Bulletin, No. 13.

Rose, Leo E. and Scholz, J. T. 1989. Nepal: Profile of a Himalayan Kingdom (Boulder, Colorado: Westview).

Rose, Leo E. 1971. Nepal: Strategy for Survival (Berkeley: University of California).

SAHRDEC's (South Asia Human Rights Documentation Centre). 1996. Midnight Knocks and Extra-Judicial Killings in Nepal (available at: http// www. hri.ca/ partners/sahrdec/enapl/fullttext).

Shaha, Rishikesh. 1990a. Modern Nepal: A Political History 1769-1955, Vol. 2 (New Delhi: Manohar).

Shaha, Rishikesh. 1990b. Politics in Nepal 1980-1990: Referendum, Stalemate and Triumph of People's Power (New Delhi: Manohar).

Sharma, Prayag Raj 1997. "Nation-Building, Multi-Ethnicity, and the Hindu State", in David Gellner, Joanna Pfaff-Czarnecka and John Whelpton (eds.), Nationalism and Ethnicity in a Hindu Kingdom (Amsterdam: Harwood Academic Publishers), pp. 471-494.

Shore, Chris and Wright, Susan, 2001. "Policy: A New Field of Anthropology", in Chris Shore and Susan Wright (eds.) Critical Perspectives on Governance and Power (London and New York: Routledge) pp. 3-39.

Shrestha, K. 1984. Monarchy in Nepal, Tribhuvan Era: Imprisonment to Glory (Bombay: Popular Prakashan).

Shrestha, N. R. and Conway, D. 1985. "Issues of Population Pressure, Land Resettlement and Development: The Case of Nepal", Studies in Comparative International Development, Vol. 20, No. 1, pp. 55-82.

Thapa, Deepak and Sijapati, Bandita 2003. A Kingdom Under Siege: Nepal's Maoist Insurgency, 1996-2003 (Kathmandu: The Printhouse).

The Independent, 13-19 December 1995. 
Uprety, Prem. R. 1992. Political Awakening in Nepal (New Delhi: Commonwcalth Puhlishers).

Word Bank. 1991. Nepal: Poverty and Incomes (Washington DC: The World Bank), pp. 3-4.

World Bank, Nepal: Policies for Improving Growth and Alleviating Poverty, Report No. 7418-NEP (Washington DC: The World Bank, 1988).

World Bank, 1990. Nepal: Relieving Poverty in a Resource-Scarce Economy, Report No. 8635-NEP, Vol. 1 (Washington DC: The World Bank).

Zaman. M. A. 1992. Evaluation of the Land Reform in Nepal (Madras: Oxford University Press)

\section{BORDER TOWN IN THE TARAI: SITES OF MIGRATION ${ }^{1}$}

\section{Sondra L. Hausner}

This paper relates the dynamics of three border towns, focusing on Nepal's southern Tarai as a belt of migration. This paper focuses on the contemporary geopolitical reality of the Tarai as a place in which both hill migrants congregate and through which migrants leave Nepal and travel to the Indian plains, in search of work, safety, and opportunity. The theoretical aspects of the paper touch on the questions of voluntary versus forced migration, and also, analogously or not, voluntary versus forced prostitution (De La Costa and Alexander 1993, Doezma 1998). It is grounded in a critique of the rhetoric of trafficking as the sole measure through which the development industry - both international and national - views the movement of women across the Nepal-India border (Fujikura 2001, O'Neill 2001), and opts rather to focus on the labor conditions of voluntary sex workers in Tarai migrant towns. Prostitution in border towns is a global reality - border crossings in the Tarai are no exception - and our reflections on this region of Nepal must include ways to ensure the proper treatment of sex workers.

Each Tarai border crossing poses a particular set of geographic, cultural, and political realities, with various histories - certain routes are more plied than others at different moments in time, which reflect variable labor and market economies in India (Rankin 2004) and, in more recent history, the Gulf, where an estimated half a million Nepali migrant wage laborers live and work (Seddon et. al 1998, Seddon 2005), almost all men. ${ }^{2}$ Women who migrate are by no means all victims of trafficking rings (Frederick 1998, Hausner 2005), but those who are trafficked are nonetheless among those who migrate. As far as we know, trafficking destinations are not usually large towns on the border. But active sending 